\title{
Enhanced SOA formation from mixed anthropogenic and biogenic emissions during the CARES campaign
}

\author{
J. E. Shilling ${ }^{1}$, R. A. Zaveri ${ }^{1}$, J. D. Fast ${ }^{1}$, L. Kleinman ${ }^{2}$, M. L. Alexander ${ }^{3}$, M. R. Canagaratna ${ }^{4}$, E. Fortner ${ }^{4}$, \\ J. M. Hubbe ${ }^{1}$, J. T. Jayne ${ }^{4}$, A. Sedlacek ${ }^{2}$, A. Setyan ${ }^{5}$, S. Springston ${ }^{2}$, D. R. Worsnop ${ }^{4}$, and Q. Zhang \\ ${ }^{1}$ Atmospheric Sciences and Global Change Division, Pacific Northwest National Laboratory Richland, WA 99352, USA \\ ${ }^{2}$ Atmospheric Sciences Division, Brookhaven National Laboratory, Upton, NY 11973, USA \\ ${ }^{3}$ Environmental and Molecular Sciences Laboratory, Pacific Northwest National Laboratory Richland, WA 99352, USA \\ ${ }^{4}$ Aerodyne Research, Inc., Billerica, MA 08121, USA \\ ${ }^{5}$ Department of Environmental Toxicology, University of California, Davis, CA 95616, USA
}

Correspondence to: J. E. Shilling (john.shilling@pnnl.gov)

Received: 26 September 2012 - Published in Atmos. Chem. Phys. Discuss.: 5 October 2012

Revised: 15 January 2013 - Accepted: 1 February 2013 - Published: 21 February 2013

\begin{abstract}
The CARES campaign was conducted during June, 2010 in the vicinity of Sacramento, California to study aerosol formation and aging in a region where anthropogenic and biogenic emissions regularly mix. Here, we describe measurements from an Aerodyne High Resolution Aerosol Mass Spectrometer (AMS), an Ionicon Proton Transfer Reaction Mass Spectrometer (PTR-MS), and trace gas detectors $\left(\mathrm{CO}, \mathrm{NO}, \mathrm{NO}_{\mathrm{x}}\right)$ deployed on the G-1 research aircraft to investigate ambient gas- and particle-phase chemical composition. AMS measurements showed that the particle phase is dominated by organic aerosol (OA) (85\% on average) with smaller concentrations of sulfate $(5 \%)$, nitrate $(6 \%)$ and ammonium (3\%) observed. PTR-MS data showed that isoprene dominated the biogenic volatile organic compound concentrations (BVOCs), with monoterpene concentrations generally below the detection limit. Using two different metrics, median OA concentrations and the slope of plots of $\mathrm{OA}$ vs. $\mathrm{CO}$ concentrations (i.e., $\Delta \mathrm{OA} / \Delta \mathrm{CO}$ ), we contrast organic aerosol evolution on flight days with different prevailing meteorological conditions to elucidate the role of anthropogenic and biogenic emissions on OA formation. Airmasses influenced predominantly by biogenic emissions had median OA concentrations of $2.2 \mu \mathrm{g} \mathrm{m}^{-3}$ and near zero $\Delta \mathrm{OA} / \Delta \mathrm{CO}$. Those influenced predominantly by anthropogenic emissions had median OA concentrations of $4.7 \mu \mathrm{g} \mathrm{m}^{-3}$ and $\Delta \mathrm{OA} / \Delta \mathrm{CO}$ ratios of $35-44 \mu \mathrm{g} \mathrm{m}^{-3} \mathrm{ppmv}$. But, when biogenic and anthropogenic emissions mixed, OA levels were enhanced, with median OA concentrations of $11.4 \mu \mathrm{g} \mathrm{m}^{-3}$
\end{abstract}

and $\Delta \mathrm{OA} / \Delta \mathrm{CO}$ ratios of $77-157 \mu \mathrm{g} \mathrm{m}^{-3}$ ppmv. Taken together, our observations show that production of OA was enhanced when anthropogenic emissions from Sacramento mixed with isoprene-rich air from the foothills. After considering several anthropogenic/biogenic interaction mechanisms, we conclude that $\mathrm{NO}_{\mathrm{x}}$ concentrations play a strong role in enhancing SOA formation from isoprene, though the chemical mechanism for the enhancement remains unclear. If these observations are found to be robust in other seasons and in areas outside of Sacramento, regional and global aerosol modules will need to incorporate more complex representations of $\mathrm{NO}_{\mathrm{x}}$-dependent $\mathrm{SOA}$ mechanisms and yields into their algorithms. Ultimately, accurately predicting OA mass concentrations and their effect on radiation balance will require a mechanistically-based treatment of the interactions of biogenic and anthropogenic emissions.

\section{Introduction}

Aerosol particles directly affect the Earth's radiation balance by absorbing and scattering solar radiation and indirectly by affecting cloud properties and lifetimes. The net anthropogenic aerosol forcing by both effects is believed to be comparable in magnitude but opposite in sign to the forcing currently attributed to anthropogenic $\mathrm{CO}_{2}$ (Solomon et al., 2007). However, the uncertainty associated with aerosol radiative forcing, particularly the indirect effect, is the largest 
source of uncertainty for global climate models (Solomon et al., 2007). Thus, improvements in global climate models require improvements in representing aerosol particles as forcing agents.

Measurements show that organic aerosol (OA) comprises $20 \%$ to $90 \%$ of the total submicron aerosol mass (Kanakidou et al., 2005). Factor analysis of Aerodyne Aerosol Mass Spectrometer (AMS) data collected at numerous locations in the Northern Hemisphere has shown that the oxygenated organic aerosol, which is a proxy for secondary organic aerosol (SOA), is the largest component of the OA mass, comprising between 63 and $95 \%$ of the total (Zhang et al., 2007; Ng et al., 2010; Zhang et al., 2011). Modeling efforts have struggled to reproduce the measured OA concentrations, physical properties, and chemical properties. Early modeling studies underpredicted observed SOA concentrations by factors of 8-100 over large regions of the atmosphere (deGouw et al., 2005; Heald et al., 2005; Volkamer et al., 2006). More recent modeling efforts incorporating newly discovered SOA sources have begun to close the gap between predicted and measured SOA concentrations, though simulated SOA properties such as volatility and O:C ratio may be very different from the observations (Dzepina et al., 2009; Hodzic et al., 2010; Slowik et al., 2010). In regions of the atmosphere free of anthropogenic influence, some updated models may reproduce the observed OA concentrations with reasonable accuracy (Slowik et al., 2010), though it remains unclear if agreement is a result of adequately parameterizing the dominant SOA formation processes or a fortuitous result of offsetting error. In another case, a model incorporating new SOA production schemes reproduced the measured SOA mass near Mexico City, but overpredicted the observed SOA mass downwind of the city (Shrivastava et al., 2011). The most recent generation of models appear to be particularly challenged in regions where anthropogenic and biogenic emissions mix and have suggested that anthropogenic emissions enhance SOA formation from biogenic volatile organic compounds (BVOCs), though to varying degrees (Carlton et al., 2010; Spracklen et al., 2011). Carleton et al. (2010) estimate that approximately $50 \%$ of the total biogenic SOA loading is from anthropogenically-controlled biogenic SOA while Spraklen et al. (2011) arrive at an estimate of $70 \%$. Regardless of the exact magnitude, these modeling studies suggest that mixing of anthropogenic and biogenic emissions significantly enhances SOA formation.

An increasing number of field measurements have also provided evidence of an anthropogenic effect on SOA formation. In the northeastern United States, de Gouw et al. observed a strong correlation of OA with acetylene and alkyl nitrates, tracers of anthropogenic emissions (deGouw et al., 2005). However, they could not explain the observed OA concentrations based on traditional yields of the measured anthropogenic precursors alone and suggested pollution may enhance OA formation from biogenic precursors (deGouw et al., 2005). Another study showed similar strong corre- lations between anthropogenic VOCs, such as glyoxal, and OA concentrations (Volkamer et al., 2006). Measurements of water-soluble organic compounds (WSOC) in fine particles in the Atlanta metro area showed high correlations with anthropogenic emission tracers, such as $\mathrm{CO}$ and anthropogenic VOCs (Weber et al., 2007; Sullivan and Weber, 2006). However, despite sampling in a region heavily influenced by biogenic VOC emission, little correlation between biogenic VOCs and WSOC concentrations was found (Weber et al., 2007). Simultaneously, radioisotope analysis showed that $80 \%$ of the particle-phase carbon mass was modern in origin, suggesting the WSOC was largely SOA formed from biogenic emissions (Weber et al., 2007). Radiocarbon analysis of fine particulate matter collected at twelve additional sampling sites in the United States showed that modern carbon composed $50 \%, 70-97 \%$, and $82-100 \%$ of the total carbon at urban, near urban, and remote sites, respectively, again suggesting that much of the OA mass originates from modern carbon, particularly downwind of urban areas (Schichtel et al., 2008). Goldstein et al. (2009) report that satellite observations of aerosol optical thickness over the SE US showed spatial and seasonal patterns that were consistent with $\mathrm{OA}$ formation from biogenic precursors and hypothesized that anthropogenic $\mathrm{NO}_{\mathrm{x}}$ and $\mathrm{SO}_{2}$ emissions modulated SOA formation from biogenic VOCs (Goldstein et al., 2009). Taken together, the field observations suggest that much of the SOA mass forms from biogenic precursors through some mechanism that is either driven or enhanced by anthropogenic emissions.

Laboratory studies have provided insights into potential mechanisms by which anthropogenic emissions may enhance SOA formation from biogenic precursors. Partitioning theory predicts that primary anthropogenic carbonaceous particles should enhance SOA formation from BVOCs (Odum et al., 1996; Pankow, 1994) through Raoult's-Law effects, though measurements suggest that biogenic SOA is soluble in some but not all primary anthropogenic particles (Song et al., 2007; Asa-Awuku et al., 2009). Acidification of aerosol particles has been show to increases SOA yield through acid catalyzed oligomer formation (Gao et al., 2004; Offenberg et al., 2009; Jang et al., 2002). $\mathrm{NO}_{\mathrm{x}}$ concentrations have also been shown to affect SOA yield by affecting gas-phase oxidation pathways. Studies of SOA formation from isoprene found that the highest SOA yield is achieved at VOC: $\mathrm{NO}_{\mathrm{x}}$ ratios of $1-5$ (ppbv C:ppbv $\mathrm{NO}_{\mathrm{x}}$ ) with lower values measured at both higher and lower ratios (Kroll et al., 2005; Kroll et al., 2006; Dommen et al., 2006; Chan et al., 2010). Later experiments elucidated the role of $\mathrm{NO}_{\mathrm{x}}$ in determining isoprene gas-phase isoprene oxidation mechanisms and subsequent SOA products. Under low- $\mathrm{NO}_{\mathrm{x}}$ conditions, first-generation isoprene peroxyradicals react primarily with $\mathrm{HO}_{2}$ to form peroxides which undergo further oxidation to produce isoprene epoxydiols (Surratt et al., 2010; Chan et al., 2010). In the presence of acidic sulfate seed aerosol, these isoprene epoxydiols undergo heterogeneous reactions 
to form organic-sulfate esters (Surratt et al., 2008) and furan diols (Lin et al., 2012) leading to efficient SOA formation, especially at low relative humidity (Surratt et al., 2010). Under high- $\mathrm{NO}_{\mathrm{x}}$ conditions, first-generation isoprene peroxyradicals react with $\mathrm{NO}$ to generate methacrolein (MACR) and methylvinyl ketone (MVK). In the presence of $\mathrm{NO}_{2}, \mathrm{OH}$ oxidation of MACR produces methacryloyl peroxy nitrate (MPAN), which can undergo subsequent oxidation to form significant SOA (Chan et al., 2010; Surratt et al., 2010).

Additional hereto unidentified multigenerational chemistry of semi- or intermediate-volatility biogenic species could potentially enhance SOA yields through the enhanced oxidant concentrations found in urban plumes. This process has been identified as important for semi-volatile anthropogenic emissions (Robinson et al., 2007). However, gasphase aging of biogenic species has been largely unstudied and it is unclear if this mechanism significantly enhances isoprene SOA yields. Very recent laboratory results suggest gas-phase aging by $\mathrm{OH}$ increases the yield for $\alpha$-pinene SOA (Donahue et al., 2012). Additional mechanisms, such as oxidation of VOCs by $\mathrm{NO}_{3}$; oxidation of wood-smoke, forest fire, and other biomass burning emissions; in-cloud aqueousphase processing; and irreversible partitioning may also play a role in certain regions (Hoyle et al., 2011; Vaden et al., 2011; Carlton et al., 2006; Ervens et al., 2008; Perraud et al., 2012).

The Carbonaceous Aerosol Radiative Effects Study (CARES) conducted in and around Sacramento, CA was designed to investigate potential interactions of biogenic and anthropogenic emissions (Zaveri et al., 2012). Sacramento's location and the surrounding terrain make it an ideal site for investigating anthropogenic/biogenic interactions. Sacramento is a relatively isolated, medium sized city in California's central valley. Strong sources of biogenic emissions are found $\sim 40 \mathrm{~km}$ to the east in the foothills of the Sierra Nevada Mountains, with relatively few sources of either biogenic or anthropogenic emission between the city and the foothills. The terrain immediately to the north, south and west is also free from strong sources of biogenic emissions. Anthropogenic emissions from the Bay Area to the west sometimes impact Sacramento. Synoptic-scale southwesterly winds regularly transport the Sacramento emissions over the foothills on timescales of several hours, making it amenable to study mixing of fresh anthropogenic and biogenic emissions during the course of the day. Passages of mid to lower tropospheric troughs shift the wind direction to the northwest, providing opportunities to evaluate the urban plume in isolation (i.e., in the absence of biogenic emissions). Here, we report observations taken onboard the Department of Energy (DOE) Gulfstream-1 (G-1) research aircraft during CARES that show SOA production is enhanced when anthropogenic emissions mix with biogenic emissions.

\section{Experimental}

As part of the CARES campaign, gas and particle phase measurements were taken during 22 research flights from 3 to 28 June 2010 onboard the G-1, in the vicinity of Sacramento, CA, over the Central Valley, and the Sierra Nevada foothills. The G-1 was based at McClellan Airfield, located approximately 10 miles NE of downtown Sacramento. An overview of the CARES campaign measurement strategy, scientific goals, and meteorology were described previously (Zaveri et al., 2012; Fast et al., 2012). The G-1 sampling strategy was to characterize the Sacramento urban plume and the surrounding air upwind and downwind of Sacramento in the morning when emissions were fresh and again in the afternoon after emissions had been aged and transported. This quasiLagrangian strategy allows for the development and aging of the urban plume to be examined. Typically, the morning flight occurred between 09:00-12:00 local time (PDT) with the afternoon flight lasting from 15:30 to 18:30 PDT. A full list of the flight times are provided in Zaveri et al. (2012). Research flights were conducted only on clear or mostly clear days. Unless otherwise noted, data described in this paper were collected at an altitude of $305 \mathrm{~m}$ above ground level and at a nominal true air speed of $100 \mathrm{~m} \mathrm{~s}^{-1}$. Each flight usually included one or more spiral ascent to higher altitudes to determine the vertical profile of meteorological parameters, aerosol properties, and trace gases.

Flight paths were developed based on the prevailing wind direction and meteorology. When prevailing winds were from the southwest (SW), the Sacramento plume was transported toward the foothills, a major source of biogenic emissions. The underlying terrain for most of this flight path was dominated by hardwoods (primarily oak) that primarily emit isoprene; flights discussed herein did not penetrate deeply enough into the Sierra Nevada to pass over the conifers that grow at higher elevations and emit monoterpenes. Measurements during SW flow conditions therefore represent an opportunity to evaluate SOA formation and aging when anthropogenic emissions mix with biogenic emissions. In contrast, when prevailing winds were from the northwest, the urban plume was transported from the Sacramento valley into the San Joaquin Valley where the terrain was dominated by agricultural use and rangeland. The G-1 did not fly over the foothills on NW flow days; therefore relatively little biogenic emission were encountered (except at the eastern ends of some flight legs) and the urban plume evolved in the absence of strong biogenic influence. Contrasting the plume evolution under different meteorological conditions provides an opportunity to examine the effect of anthropogenic/biogenic interactions.

The chemical composition of the non-refractory aerosol particles was measured with an Aerodyne High-Resolution Time-of-Flight Aerosol Mass Spectrometer (AMS) (DeCarlo et al., 2006; Jayne et al., 2000). In the AMS, particles are focused into a narrow beam by an aerodynamic lens (Liu et 
al., 1995) and impacted onto a resistively heated $\left(600^{\circ} \mathrm{C}\right)$ ceramic oven. Non-refractory components (operationally defined as components that vaporize in $\sim 2 \mathrm{~s}$ ) are volatilized, the vapor plume is ionized by electron impact at $70 \mathrm{eV}$, ions are extracted into a time of flight chamber where they are separated by velocity, and detected with a microchannel plate. For this study, only the higher sensitivity "V" mode of the mass analyzer was employed. Mass spectra are analyzed with standard software as described in the literature to chemically resolve particle components (Allan et al., 2004; Aiken et al., 2007). The AMS recorded an average mass spectrum every $13 \mathrm{~s}$ or roughly 0.65 miles $(1.04 \mathrm{~km})$ at the G-1 flight speed. Interferences from gas phase species were subtracted from the data based on the signal observed when sampling air diverted through a HEPA filter; filter data were collected for approximately $5 \mathrm{~min}$ before, during, and after each flight. The ionization efficiency (IE) of the instrument was regularly calibrated during the campaign with monodisperse ammonium nitrate particles using the single particle sampling mode (i.e., BFSP mode). The IE calibrations were stable through the campaign; therefore, all calibration data were averaged and a single calibration was applied to all the flight data. To account for real-time changes in instrument sensitivity as the instrument warmed up during the flights, the mass spectral signal at $m / z 28\left(\mathrm{~N}_{2}^{+}\right)$was normalized to the average value of the same signal obtained during calibration runs to generate a real-time correction factor (i.e., the "airbeam correction") that was applied to the data. In general, the magnitude of this correction was less than $10 \%$. Based on in-flight filter measurements, AMS detection limits for a $13 \mathrm{~s}$ averaging time are approximately $0.3,0.07,0.05$, and $0.15 \mu \mathrm{g} \mathrm{m}^{-3}$ for organics, sulfate, nitrate, and ammonium, respectively though they vary with the instrument pump-down time (DeCarlo et al., 2006).

Ambient aerosol particles are sampled using a common isokinetic inlet on the G-1. A portion of the total aerosol flow in the isokinetic inlet was split from a $1 / 4^{\prime \prime}$ copper pickoff port for AMS sampling. To maintain a constant pressure in the AMS lens, a pressure controlled inlet (PCI) was added between the $1 / 4^{\prime \prime}$ pickoff port and the AMS lens (Bahreini et al., 2008). The PCI maintains a constant pressure $(\sim 620 \mathrm{mbar}$ for this study) in the AMS sampling line by pumping a controlled and variable flow $(0-300 \mathrm{ccm})$ across a $0.20 \mathrm{~mm}$ orifice. A second $0.13 \mathrm{~mm}$ orifice downstream of the first maintains constant volumetric flow into the AMS lens. The orifice sizes were chosen to maintain a lens pressure of 1.77 mbar, which is operating pressure of the lens under standard conditions (i.e., at sea level in the absence of a pressure controlled inlet), at the highest altitude we expected to sample. All calibrations were performed with the PCI operating as it did in-flight. All species mass concentrations are referenced to a temperature of $23^{\circ} \mathrm{C}$ and 1 atmosphere pressure.

Volatile Organic Compounds (VOCs) were measured with an Ionicon High-Sensitivity Proton Transfer Reaction Mass Spectrometer (PTR-MS) (Lindinger et al., 1998). In the PTR-
MS, analyte molecules are ionized by reaction with a high concentration of $\mathrm{H}_{3} \mathrm{O}^{+}$ions under the influence of an electrical field in a drift tube. Only molecules with a higher proton affinity than that of water undergo a reaction, making the technique sensitive to most unsaturated VOC's but insensitive to the major components of air, such as $\mathrm{N}_{2}, \mathrm{O}_{2}$, $\mathrm{CH}_{4}, \mathrm{CO}$ and $\mathrm{CO}_{2}$. Ionized molecules are then filtered with a quadrupole mass spectrometer and detected with an electron multiplier. The drift tube temperature was maintained at $60^{\circ} \mathrm{C}$, the pressure in the drift tube was maintained at $2.2 \mathrm{mbar}$ by a pressure controller, and the voltage across the $9.2 \mathrm{~cm}$ drift tube was maintained at $600 \mathrm{~V}$, resulting in an $\mathrm{E} / \mathrm{n}$ of $136 \mathrm{Td}$. The quadrupole was set to sequentially step through a series of 17 masses (13 research masses and 4 diagnostic masses) with a $100 \mathrm{~ms}$ dwell time on each research mass. After allowing for settling time of the quadrupole voltages, this sampling strategy yielded a time resolution of one full cycle of measurements every $3.4 \mathrm{~s}$. Air was supplied to the PTR-MS from a forward facing inlet through approximately $15 \mathrm{ft}$. of 0.07 ID" PEEK capillary tubing, the final 3 feet of which were heated to $60^{\circ} \mathrm{C}$. Ambient air was periodically diverted through a stainless steel tube filled with a Shimadzu platinum catalyst heated to $500^{\circ} \mathrm{C}$, which catalytically converts VOCs in the air to $\mathrm{CO}_{2}$. Comparison of ambient air sampled through the heated catalyst with air from a cylinder of certified VOC-free air showed the catalyst was effective at removing VOCs to the instrument detection limit. Ion intensities observed while sampling through the catalyst were taken as the instrument background and subtracted from the experimental measurements. These backgrounds were taken before, during, and after the flights with the readings in good agreement. Because the PTR-MS was powered down nightly after flights, instrument backgrounds at most masses are higher than normal, which also increases the instrument detection limit. Using the method and definitions described by Amann et al. (2010), we estimate the PTRMS limit of quantification for isoprene, methacrolein and methyl-vinyl ketone, benzene, toluene, and monoterpenes as $500,550,750,600$, and 300 pptv respectively (Amann et al., 2010). Gas concentrations were calculated from calibrations conducted regularly during the campaign by sampling from gas cylinder containing known concentrations the VOC's of interest.

Ions with the same nominal mass were not separated by the PTR-MS and therefore signal at a particular mass-to-charge may have contributions from several species. In this work, we assign the signal at $m / z, 69$ as isoprene and $m / z, 71$ as the sum of methacrolein and methyl-vinyl ketone (MVK + MACR). We note that the signal at $\mathrm{m} / \mathrm{z}, 69$ may also originate from fragmentation of larger molecules in diesel exhaust or gasoline (Jobson et al., 2005), furan in biomass burning plumes (Warneke et al., 2011), and alkenes (Karl et al., 2007). Similarly, $m / z 71$ may also originate from fragmentation of larger molecules in diesel exhaust or gasoline (Jobson et al., 2005), pentene and its isomers (Warneke et al., 2003), and higher 
alkenes (Karl et al., 2007). While we cannot rule out small contributions from these compounds to the signal, we argue the signal at $\mathrm{m} / \mathrm{z} 69$ and $\mathrm{m} / \mathrm{z} 71$ is dominated by isoprene and MVK + MACR, respectively, in this study for the following reasons. First, we observe a tight correlation between $\mathrm{m} / \mathrm{z} 69$ and $\mathrm{m} / \mathrm{z} 71$, suggesting they come from a similar source. Second, there is a poor correlation between $\mathrm{m} / \mathrm{z}, 69$ and 71 with other VOCs typically associated with urban and industrial emissions, such as benzene and toluene. There is a poor correlation between $\mathrm{m} / \mathrm{z} 69$ and 71 with $\mathrm{m} / \mathrm{z}$ 43, a common fragment of diesel exhaust, higher alkenes, and pentenes (Jobson et al., 2005; Warneke et al., 2003). Isoprene and its oxidation products were not present at concentrations larger than 1 ppbv over the city during most flights, and were only observed over the city when nighttime winds were from the east, suggesting these emissions do not originate from Sacramento. Biogenic emission estimates based on the MEGAN model (Guenther et al., 2006) also indicate that emission rates are low near Sacramento and high in the foothills (Zaveri et al., 2012).

Air for $\mathrm{CO}$, ozone, $\mathrm{NO}$, and $\mathrm{NO}_{2}$ measurements was drawn from a forward facing $1 / 2$ " PFA Teflon. Inside the aircraft, 1/4" PFA taps fed individual instruments. Carbon monoxide was measured by a research-grade instrument built by Brookhaven National Laboratory (BNL) and Resonance Limited (Ontario, Canada). The unit selectively measures CO by resonance fluorescence at $150 \mathrm{~nm}$ using a sealed CO discharge lamp and a 5-element dichroic mirror excitation filter (Volz and Kley, 1985). The fluorescence signal is measured by a photomultiplier tube (Hamamatsu R6834 with photon counting) with a 1-s time resolution. The instrument optics were purged with high-purity argon gas to eliminate interference. Calibrations were performed in-flight by introducing standard additions of $\mathrm{CO}$ from a reference cylinder to the instrument every 20 or $40 \mathrm{~min}$. Because the instrument response varied with warm-up and purging efficiency, ambient concentrations were calculated using a spline fit to the standard addition calibrations. The instrument was zeroed every $20 \mathrm{~min}$ by diverting ambient air through Sofnocat Catalyst (Molecular Products, New York, NY) at room temperature. The instrument detection limit is approximately $3 \mathrm{ppbv}$. The flow rate through the instrument limits its practical time response to $2-5 \mathrm{~s}$.

Ozone was measured using a modified Model 49-100 UV Absorbance $\mathrm{O}_{3}$ Analyzer (Thermo Electron Corporation, Franklin, MA). Modifications were made to the internal ozonizer so that in-flight zeros and span checks were made every other hour. This unit is calibrated regularly against the NY State Department of Environmental Conservation NISTtraceable standard. The expected uncertainty in response is $\sim 5 \%$ (3 S.D.) and the detection limit is approximately 3 ppbv.

$\mathrm{NO}$, and $\mathrm{NO}_{2}$ were measured using an instrument designed and constructed at BNL. The instrument measures NO directly by detecting the chemiluminescence resulting from reaction with added $\mathrm{O}_{3} . \mathrm{NO}_{2}$ is converted to $\mathrm{NO}$ by photolytic reduction using a bank of 6 high-power LEDs ( $395 \mathrm{~nm}, \sim 175 \mathrm{~mW}$ each) followed by detection as NO. Calibration standards of $\mathrm{NO}$ and $\mathrm{NO}_{2}$ are added to the ambient air in flight to measure the instrument sensitivity and background of all three channels. Converter efficiency for the photolysis cell (0.71) was assessed by partially titrating a fraction of the $\mathrm{NO}$ standard with $\mathrm{O}_{3}$. The zero background was measured every $10 \mathrm{~min}$ by pre-reacting the ambient air with reagent $\mathrm{O}_{3}$.

\section{Results and discussion}

\subsection{Overview of measurements}

The average chemical composition of the non-refractory submicron aerosol particles sampled during all CARES flights is shown in Fig. 1. Organics dominate the particle phase chemical compositions, accounting for $85 \%$ of the total particle mass. Sulfate and nitrate account for 5 and $6 \%$ of the particle mass, respectively with the balance ammonium. On average, the measured ammonium mass is approximately $20 \%$ less than that required for full neutralization of the measured anion mass. Typical error on AMS mass measurements is $\sim 30 \%$ (Canagaratna et al., 2007). In the case of ammonium, much of the error comes from the determination of the relative ionization efficiency (RIE), particularly when using the field-employed calibration method. The standard deviation of the ammonium RIE determination was $13 \%$, again suggesting that the ammonium deficiency could be similar in magnitude to the measurement and calibration error. However, the anion/cation balance changes with the age of the airmass and with altitude, possibly suggesting the presence of organic sulfates or organic nitrates in the particle phase (Zaveri et al., 2012). The subjects of anion/cation balance, organic nitrates, and organic sulfates measured by the AMS as the $\mathrm{T} 1$ ground site are dealt with extensively in Setyan et al. (2012).

The organic fractions of the total fine particle mass reported in the literature are highly variable; Kanakidou et al report a range of 20-90\% (Kanakidou et al., 2005) while Zhang et al. report a range of $18-70 \%$ (Zhang et al., 2007) over a wide range of sites. Therefore, the organic fraction reported $(85 \%)$ here is at the upper end of what is reported in the literature. This can likely be explained by the fact that flights occurred only during the day, around the times of peak organic levels, and were targeted at finding OA plumes, all of which bias observations towards higher OA levels. The G-1 AMS organic fraction is similar to the organic fractions of $80 \%$ reported for the CARES T1 site (Setyan et al., 2012) and larger than the organic fraction of $63 \%$ measured at the CARES T0 site. The dominance of the fine particulate mass by organics suggests that aerosol levels are controlled by 


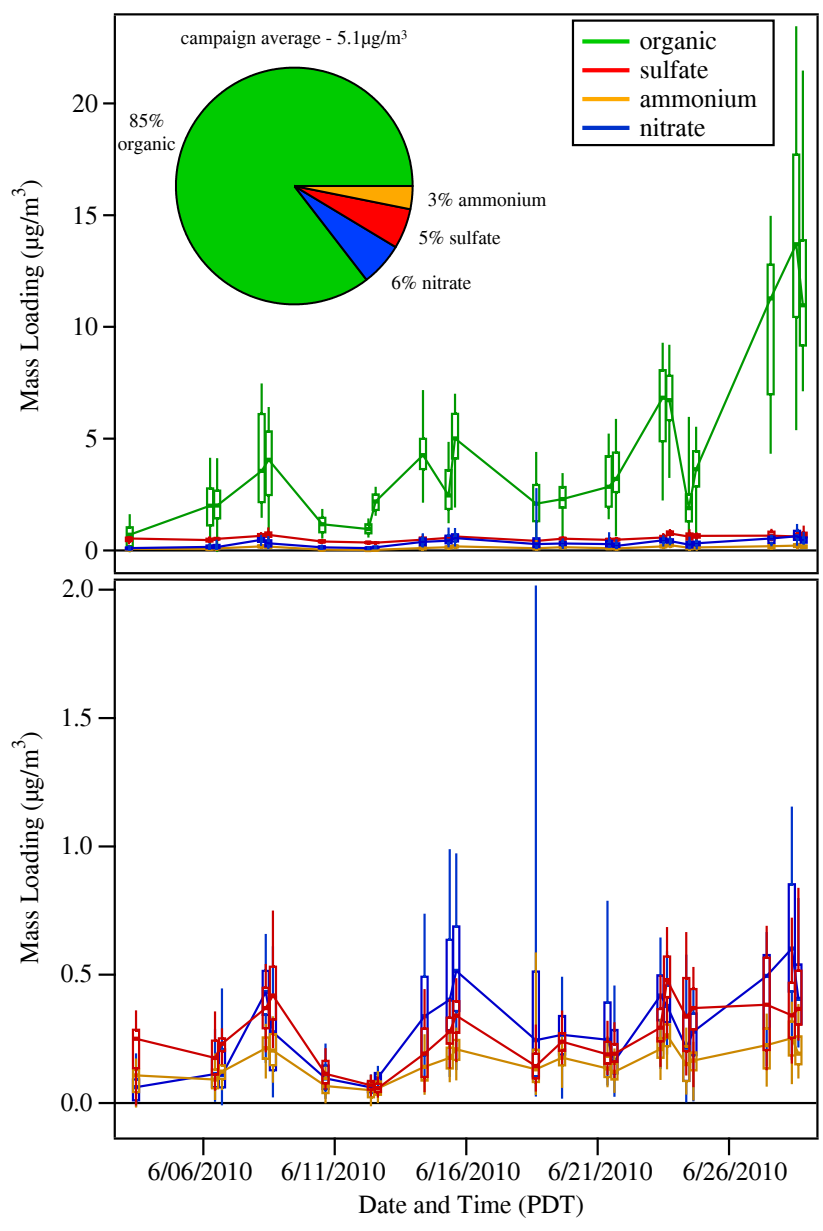

Fig. 1. Box and whisker representations of the AMS-observed nonrefractory submicron aerosol organic, sulfate, nitrate, and ammonium mass. Each point represents data from one flight of the G-1 research aircraft. Boxes represent the upper and lower quartiles and whiskers represent the 5 th and 95 th percentiles. The inset in the top panel shows the average particle chemical composition across all flights. Lines connect the median of each point and are shown to guide the eye.

SOA formation to a much larger extent in the Sacramento region than in other regions of the US.

Figure 1 also shows box and whisker plots of the speciated aerosol mass for each flight, which provides a more detailed view of the temporal differences in aerosol composition. Organic aerosol levels are generally higher in the afternoon flights than in the morning, as would be expected if SOA is influencing OA levels. Generally, the organic levels are much more variable than the sulfate concentrations, which do not show the intense buildup toward the end of the campaign displayed by organics. The lower variability in sulfate concentration suggests that its sources are regional and largely unaffected by variability of local emissions, consistent with our hypothesis that the major sources of sulfate for the Sacramento region are the refineries located along the
Carquinez Strait, approximately 60 miles to the SW of the city (Setyan et al., 2012; Zaveri et al., 2012). Nitrate levels are more variable than sulfate levels, but less so than organics. Based on the measured anion/cation mass balance and the large sources of ammonia in the Sacramento Valley, it is likely that most of the particulate nitrate mass is ammonium nitrate, though some of nitrate mass may also come from organic nitrates. We again note that all G-1 flights occurred at similar times and only during daylight hours, so they will not capture the diurnal variability observed at the ground sites (Setyan et al., 2012).

\subsection{Mixed anthropogenic/biogenic plume evolution}

As show in Fig. 1, a buildup of aerosol in the Sacramento area occurred toward the end of the campaign, with peak concentrations observed on 28 June. In addition, WRF-Chem tracer forecasts shown in Fig. 2 illustrate the transport of the Sacramento plume over the foothills of the Sierra Nevada during the afternoon (Fast et al., 2012). The high OA levels and the transport pattern make 28 June an attractive candidate for detailed discussion. Figure 2 shows that emissions from the Sacramento area are concentrated in the morning in the vicinity of downtown Sacramento and along I-80 corridor to the NE. The simulations (not shown) also predict that a portion of the urban emissions from the previous day were first transported to the foothills, and then recirculated back over the Sacramento area by nighttime easterly winds (not shown) several hundred meters above the surface, similar to the recirculation event during the evening of 22-23 June described in Fast et al. (2012). During this recirculation event, biogenic emissions from the foothills are mixed with the urban plume by the growing morning boundary layer. Thus, based on the simulations, the airmass sampled by the G-1 in the morning is expected to contain mixtures of biogenic and anthropogenic emissions.

A significant fraction of the $\mathrm{CO}$ in the Sacramento region in the morning originated from the Bay Area; however, these emissions are concentrated above the nighttime boundary layer and move out in front of the Sacramento urban plume over the Sierra Nevada Mountains or south into the San Joaquin Valley as thermally-driven winds develop aloft. By the afternoon, the contribution from the Bay Area has diminished significantly by transport. In contrast, the tracer forecasts showed that the Sacramento urban plume was transported primarily toward the foothills during the afternoon, where it interacted with fresh biogenic emissions. Therefore, the evolution of the Sacramento plume during the afternoon of 28 June should be relatively free of fresh Bay Area emissions, simplifying interpretation of the data. We note that aged regional emissions elevated $\mathrm{CO}$ and $\mathrm{OA}$ background levels across the CARES flight domain toward the end of the campaign, including on 28 June.

Figure 3 shows the spatial distributions of $\mathrm{CO}$, a tracer for anthropogenic emissions; the sum of isoprene, methyl vinyl 


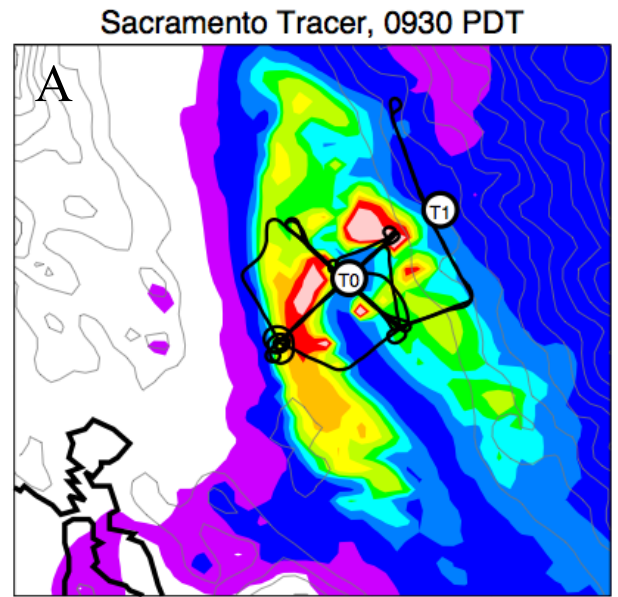

Sacramento Tracer, 1430 PDT

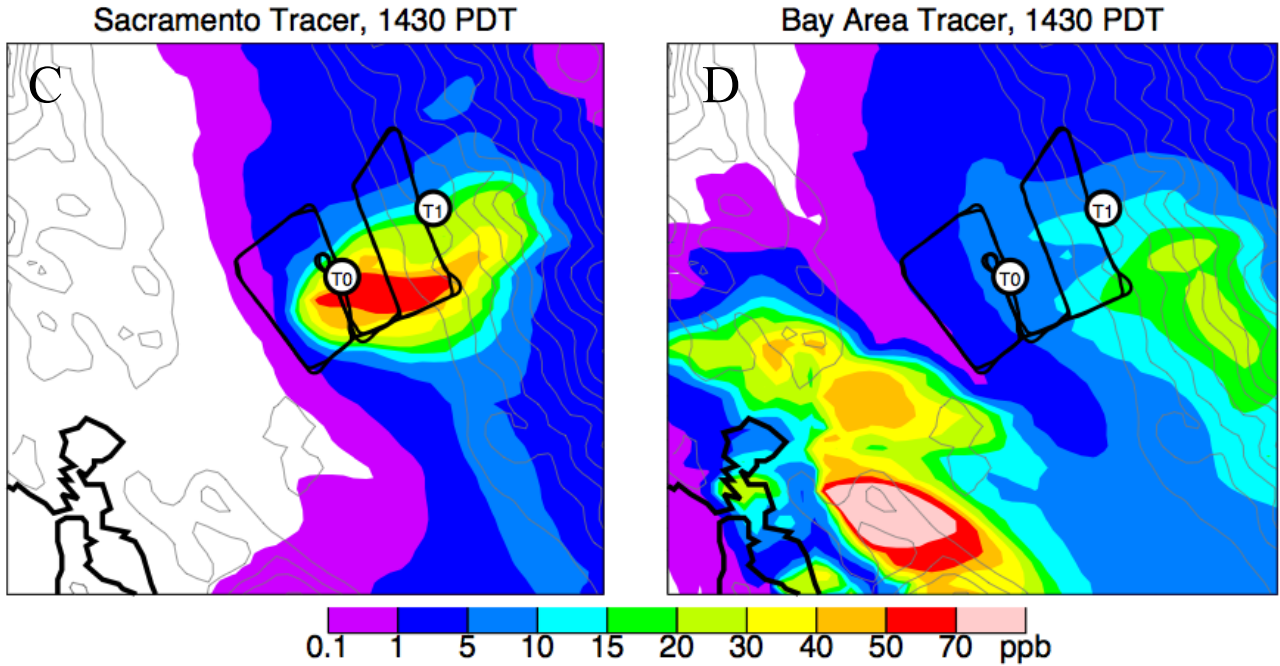

Bay Area Tracer, 0930 PDT

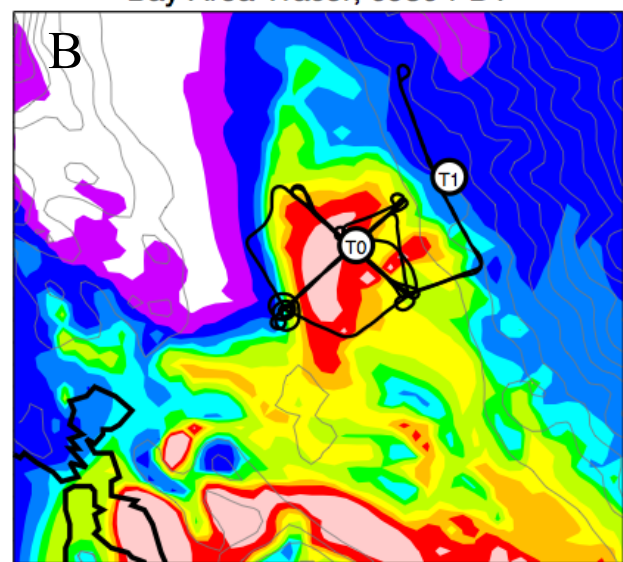

Bay Area Tracer, 1430 PDT

Fig. 2. WRF-Chem tracer forecasts of CO concentrations over central California on 28 June. Panels A and C show the Sacramento urban area CO forecasts at 09:30 and 14:30 PDT respectively, which represent the approximate takeoff time of the morning and afternoon G-1 flights. (B) and (D) show CO forecasts at the same times for the Bay Area emissions. The color scale indicates the level of CO above the background. The solid black line is the G-1 flight path and the markers show the locations of the ground sites.

ketone (MVK), and methacrolein (MACR), oxidation products of isoprene and tracers for biogenic emissions; and $\mathrm{OA}$ levels along the morning and afternoon G-1 flight paths. Figure 4 shows the same data in addition to ozone concentrations and the OA O:C elemental ratios plotted temporally. In the morning flight, the G-1 took off from McClellan airfield at 09:23 PDT and flew three legs along a NE/SW flight path, along the axis of the plume transport. At the end of the third leg, the G-1 performed a spiral climb (labeled a in Figs. 3 and 4) to $2573 \mathrm{~m} \mathrm{AGL}$, descended to $384 \mathrm{~m}$, and flew north again along the same line. It then flew three plume transect legs, traveling directly over McClellan and the T0 site perpendicular to the direction of the plume transport (labeled $b$ in Figs. 3 and 4). The G-1 then performed one plume transect to the south of the city and proceeded to the foothills where it flew two legs perpendicular to the wind over the $\mathrm{T} 1$ site (labeled $\mathrm{c}$ and $\mathrm{d}$ in Figs. 3 and 4). Finally, the G-1 returned to the metro area where it repeated two flight legs over the T0 site before landing.

As seen in Figs. 3 and 4, the G-1 encountered an intense plume (indicated with an arrow, a dashed pink line and the label " $b$ " respectively) in the morning to the southeast of the city center. Passage through the plume is indicated by elevated concentrations of $\mathrm{CO}$ of up to $300 \mathrm{ppbv}$ and OA loadings in excess of $25 \mathrm{\mu g} \mathrm{m}^{-3}$. In both the morning and the afternoon, $\mathrm{CO}$ and $\mathrm{OA}$ concentrations are well correlated, with $\mathrm{r}$ values of 0.7 and 0.85 respectively. Figures 3 and 4 show that there is a significant amount of isoprene (up to $1.5 \mathrm{ppbv}$ ) and its first-generation oxidation products, methacrolein and methyl-vinyl ketone, (up to $4.2 \mathrm{ppbv}$ ) co-located with the CO and OA in the plume. Thus, PTR-MS observations confirm the WRF predictions that suggest biogenic-rich air from the foothills is transported back to the Sacramento urban area on the night of 27-28 June by easterly flows aloft. Intense biogenic emissions were observed on the flight leg passing over 


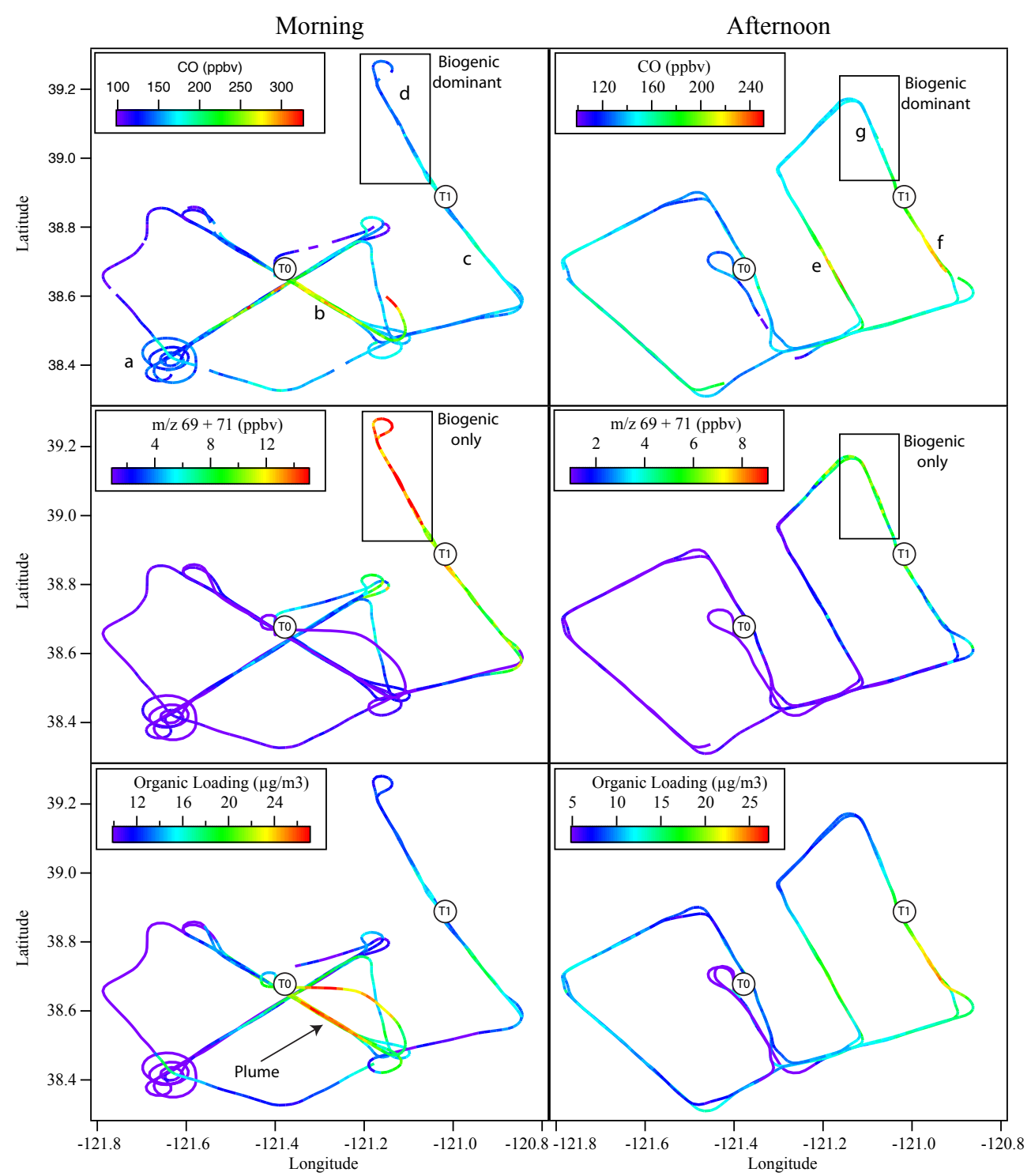

Fig. 3. 28 June G-1 morning and afternoon flight tracks colored by CO, the sum of $m / z 69$ (mainly isoprene) and 71 (MVK + MACR), and OA concentrations. The arrow indicates the mixed anthropogenic/biogenic plume. The boxed indicates the area influenced primarily by biogenic emissions. T0 and T1 symbols indicate locations of the ground sites. Letters are used to identify important portions of the flight track and correspond to the letters in shown in Fig. 4.

the T1 site. Isoprene concentrations on this leg, particularly on the northern portion (labeled d), are the highest observed throughout the campaign reaching $12.9 \mathrm{ppbv}$ around noon despite its short atmospheric lifetime under these conditions $(0.5-1 \mathrm{~h})$. Strong biogenic emissions were always observed in this region of the G-1 flight pattern, regardless of wind pattern as flights were always conducted during the daytime when high temperatures and intense sunlight promote isoprene emission. Monoterpene concentrations were below the PTR-MS detection limit ( $300 \mathrm{pptv})$ across the entire flight domain discussed in this manuscript. Significant monoterpene concentrations were measured on a single flight that penetrated deeper into the Sierra Nevada range (not shown).
The temporal profiles (Fig. 4) emphasize the spatial extent of the plume and indicate how sharp the gradients in $\mathrm{CO}$ and $\mathrm{OA}$ concentrations are between the plume and the background air. $\mathrm{CO}$ concentrations drop from their peak of $>300 \mathrm{ppbv}$ to approximately $120 \mathrm{ppbv}$ over a distance of only $19.3 \mathrm{~km}$. Organic loadings drop from their in-plume peak of $>25 \mu \mathrm{g} \mathrm{m}^{-3}$ to approximately $6 \mu \mathrm{g} \mathrm{m}^{-3}$ outside of the plume, again over a similar length scale. Figures 3 and 4 also shows that levels of isoprene and its oxidation products are near background level near the city but outside the plume, again suggesting biogenic emissions from the foothills and not from the city are by far the dominant sources of biogenic VOCs in the area. Interestingly, the O:C ratios of the OA do 


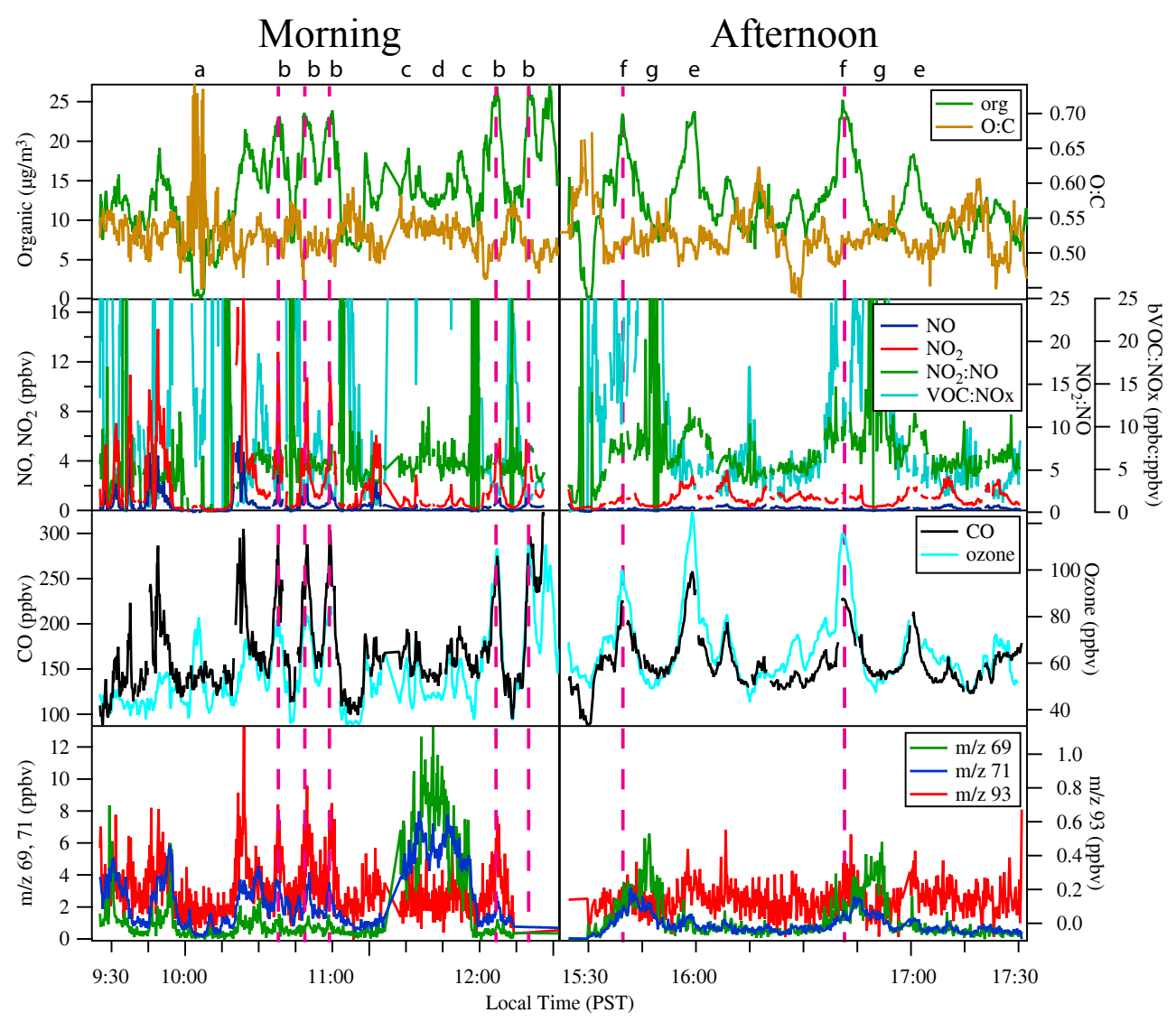

Fig. 4. Organic particle mass, organic particle $\mathrm{O}: \mathrm{C}, \mathrm{CO}$, ozone, $\mathrm{NO}, \mathrm{NO}_{2}, \mathrm{NO}_{2}: \mathrm{NO}, \mathrm{bVOC}: \mathrm{NO}_{\mathrm{x}}, m / z$, 69 (isoprene), $m / z$, 71 (MVK $+\mathrm{MACR}$ ), and $m / z, 93$ (toluene) concentrations for the morning and afternoon 28 June flights. Note there is a break in the time axis. The plume transects analyzed for Fig. 5 are indicated by the dashed pink line. Letters at the top of the graph correspond to the flight legs labeled in Fig. 3 .

not show these same sharp gradients between the OA inside and outside of the plume. The OA O:C ratio hovers around 0.51 for much of the morning flight, with slightly higher O:C (0.58) values observed to the southwest of the city and significantly larger values $(0.72)$ during the G-1 spiral ascent to $2573 \mathrm{~m}$ at 10:00 PDT. The O:C ratios observed in the plume are in excellent agreement with those observed for fresh SOA generated from the photooxidation of isoprene in the presence of $\mathrm{NO}_{\mathrm{x}}$ (Chhabra et al., 2010). No significant difference in O:C was observed between the OA located close to Sacramento and the OA located over the foothills. The mechanistic implications of the $\mathrm{O}: \mathrm{C}$ ratio observations will be discussed later in the manuscript.

In the afternoon, the G-1 left McClellan airfield at 15:21 PDT and flew a flight pattern aimed at characterizing the air upwind of Sacramento, over the city including the T0 site and McClellan, and downwind of the city over the T1 site. The right hand panels of Figure 3 and 4 show the temporal and spatial distributions of the key biogenic and anthropogenic tracers and the $\mathrm{OA}$ concentrations and $\mathrm{O}: \mathrm{C}$ ratio as before. Comparison of the left and right panels shows that the intense $\mathrm{OA}$ and $\mathrm{CO}$ plume was transported toward the NE, with the leading edge arriving SE of the T1 site by 15:30 (labeled $\mathrm{f}$ in Figs. 3 and 4) and the trailing edge found between $\mathrm{T} 0$ and T1 (labeled e in Figs. 3 and 4). The plume location predicted by the WRF-Chem forecasts (Fig. 2) is in good agreement with these measurements. The high $\mathrm{CO}$ and OA concentrations observed in this plume confirm that it is the same plume identified in the morning over the city. Therefore, this plume provides a case where the OA evolution in a single, well defined, quasi-Lagrangian air parcel can be examined over the course of the day and as it encounters further isoprene emissions.

Figure 5 shows the average concentrations of OA, the $\mathrm{O}: \mathrm{C}$ ratio, $\mathrm{CO}$, isoprene, and $\mathrm{MVK}+\mathrm{MACR}$ in the plume as it evolved over the course of the day. Each point in Fig. 5 corresponds to the average value for each pass through the plume. In calculating plume averages, we include 13 points centered about the plume maximum (defined as the maximum OA concentration) resulting in an averaging time of approximately $170 \mathrm{~s}$. Figure 5 shows that OA levels increase by $4 \mu \mathrm{g} \mathrm{m}^{-3}$ during the $1.5 \mathrm{~h}$ between the first and last pass through the plume during the morning flight. This increase in OA concentration is anticorrelated with PTR-MS 
measurements of isoprene and MVK + MACR, suggesting that second and higher generation isoprene oxidation products are key contributors to OA formation (Kroll et al., 2005; Chhabra et al., 2010). Near Sacramento, isoprene emissions are small, so the plume evolves in the morning without continuous injection of significant concentrations of fresh isoprene. While the OA concentration increases, the OA O:C ratio does not change significantly, suggesting that the fresh $\mathrm{OA}$ is chemically similar to the existing OA. CO concentrations increase slightly during the morning flight from approximately $240 \mathrm{ppbv}$ to $260 \mathrm{ppbv}$. Toluene concentrations of up to $1.2 \mathrm{ppbv}$ are observed near downtown Sacramento, but quickly drop below the PTR-MS detection limit outside the city due to oxidation and dilution. The toluene and $\mathrm{CO}$ observation indicate that fresh emissions from Sacramento are mixing into the plume, as would be expected at this time of the day. These fresh emissions undoubtedly contain some primary organic aerosol (POA), which will contribute to the increased OA concentrations measured by the AMS. However, given that the particle O:C did not change, the POA at the $\mathrm{T} 1$ site has an $\mathrm{O}: \mathrm{C}$ of 0.08 , much smaller than the observed $\mathrm{O}: \mathrm{C}$, the measured black carbon concentrations in the plume $\left(0.1-0.2 \mu \mathrm{g} \mathrm{m}^{-3}\right)$, and the PMF analysis results at $\mathrm{T} 1$ site, the POA contribution to the observed OA increase likely to be small $(<10 \%)$ (Setyan et al., 2012; Zaveri et al., 2012). In the afternoon, the plume is transported into the foothills where fresh biogenic emissions mix into the leading edge of the plume, as indicated in Fig. 3, label "f". In the 62 minutes between the first and second pass through the plume in the afternoon, the $\mathrm{OA}$ mass increases by $3.5 \mu \mathrm{g} \mathrm{m}^{-3}$; again the $\mathrm{OA}$ concentration is anticorrelated with concentrations of isoprene and MVK + MACR suggesting second and higher generation isoprene oxidation products partition to the particlephase.

Comparing the morning to the afternoon flights through the plume, absolute concentrations of OA and CO both decrease, indicating that evolution of the plume is also affected by dilution. Correcting for dilution provides a more complete and accurate picture of the OA production in the plume; however this correction is highly sensitive to the choice of the background $\mathrm{CO}$ and OA concentrations. Figure 5 shows corrected OA concentrations calculated by using $\mathrm{CO}$ as a dilution tracer assuming two different background conditions for two limiting cases. In the first case, we assume dilution is primarily through mixing with boundary layer air outside the plume but within the G1 flight domain. For this case, calculated background $\mathrm{CO}$ and $\mathrm{OA}$ concentrations are taken from the northwestern portion of the flight path as $145 \mathrm{ppb}$ and $8.9 \mu \mathrm{g} \mathrm{m}^{-3}$, respectively. In the second case, we assume dilution is primarily through vertical mixing with free tropospheric air. For this case, we take the background $\mathrm{CO}$ and OA concentrations as the average of those values measured in the free troposphere during the morning flight spiral ascent, obtaining $141 \mathrm{ppb}$ and $0.6 \mu \mathrm{g} \mathrm{m}^{-3}$, respectively. The dilution corrected OA loadings are shown in Fig. 5 and in-

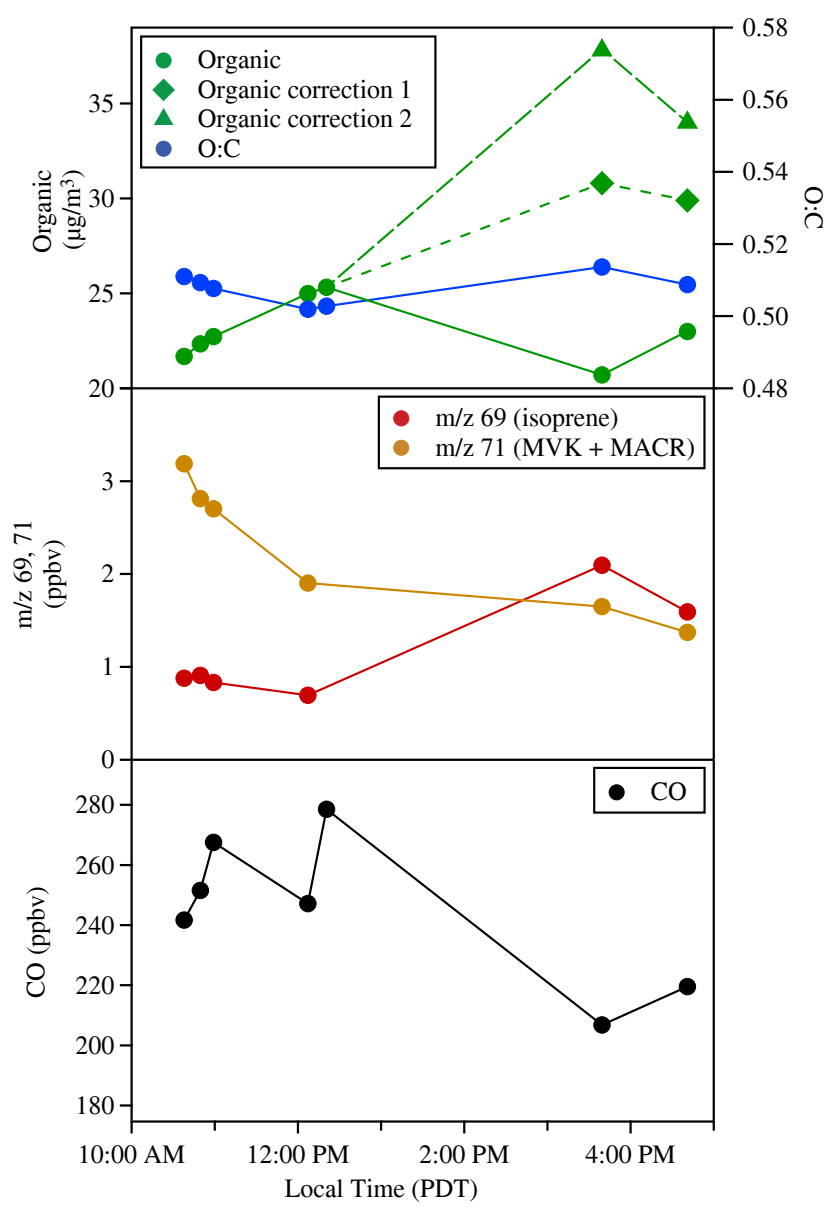

Fig. 5. Evolution of the average concentrations of OA, CO, and biogenic tracers within the mixed anthropogenic/biogenic plume on the 28 June flights. Each point is the average of approximately $170 \mathrm{~s}$ of data centered about the point of maximum OA for each pass of the G-1 through the plume (indicated by the pink line in Fig. 4). Lines are shown to guide the eye.

dicate that between 8.2 and $12.3 \mu \mathrm{g} \mathrm{m}^{-3}$ of OA mass was added in approximately $8 \mathrm{~h}$ as the plume evolved. Despite this large increase in OA mass, the chemical composition of the OA did not change significantly as the plume evolved. Figures 4 and 5 show that the O:C ratio of the plume is consistently between 0.5 and 0.55 . Figure 6 shows a comparison of the OA mass spectrum from the morning and afternoon flights, which again indicates little change in chemical composition. The implications of the AMS observations for the mechanism responsible for SOA formation are discussed in section 3.6. However, literature smog chamber isoprene yields (Kroll et al., 2005; Kroll et al., 2006) (4\%) together with estimates of the concentration of fresh biogenic emissions consumed (isoprene + 1.65.(MVK + MACR)), particularly for the morning portion of the flight when biogenic emissions are a minimum, cannot explain the measured increase in OA mass, suggesting that some mechanism is 


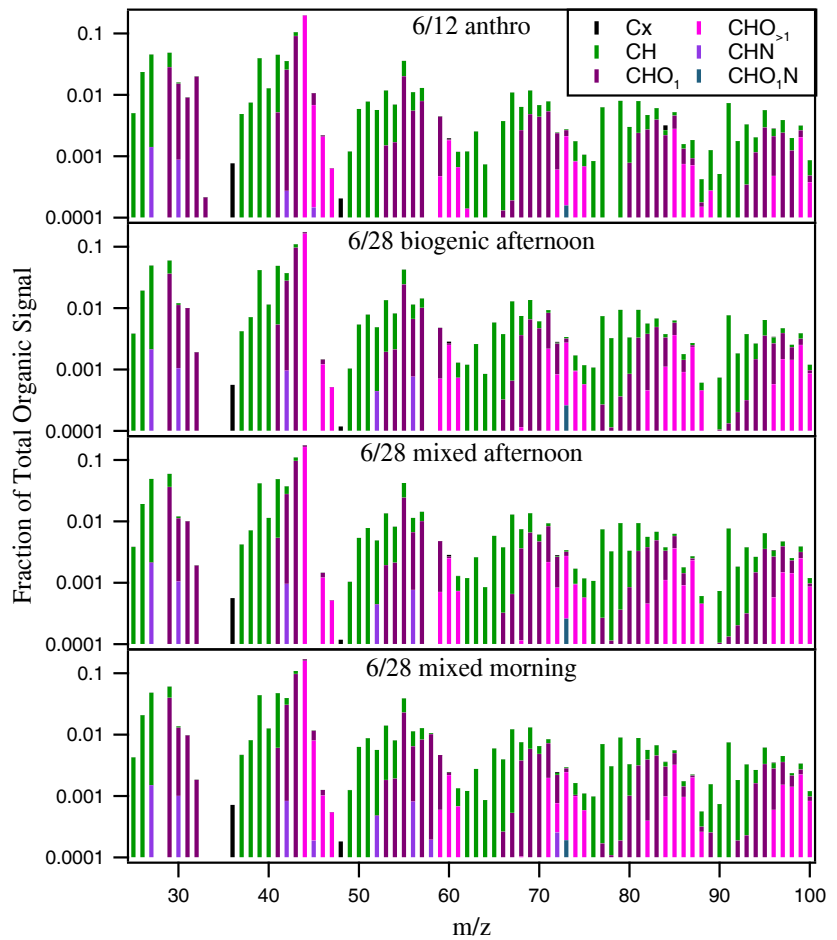

Fig. 6. Representative HR-AMS spectra of the OA sampled during CARES for the airmasses discussed in detail in the text. Each spectrum is divided by the total OA loading over that period such that spectral peaks represent a fraction of the total organic signal. Intensity at each nominal amu is broken down into the ion family shown in the legend. Only signal from organic ions is shown.

enhancing OA formation. Below, we detail additional evidence that suggests anthropogenic emissions from the city are enhancing the formation of biogenic OA.

\subsection{Biogenic dominant plume evolution}

The G-1 data from the 28 June flights also provide a convenient dataset to compare and contrast SOA formation in an airmass influenced by both fresh anthropogenic and biogenic emissions with an airmass influenced primarily by biogenic emissions and aged anthropogenic emissions. In the morning flight, we observe an area of intense biogenic emissions at the northernmost part of the leg flying over the T1 site, with isoprene concentrations as high as $13.3 \mathrm{ppbv}$ and MACR + MVK concentrations as high as 8 ppbv. The terrain under this portion of the flight leg is the most densely wooded and least populated portion of the flight track, so it is expected that biogenic emissions are highest in this area. Indeed, emission inventories predict increasing biogenic emission to the north and west of the T1 site, consistent with observations. In the afternoon, we again observed the highest concentrations of isoprene and its oxidation products along this section of the flight leg. Toluene concentrations in this region remain below the PTR-MS detection limit both in the

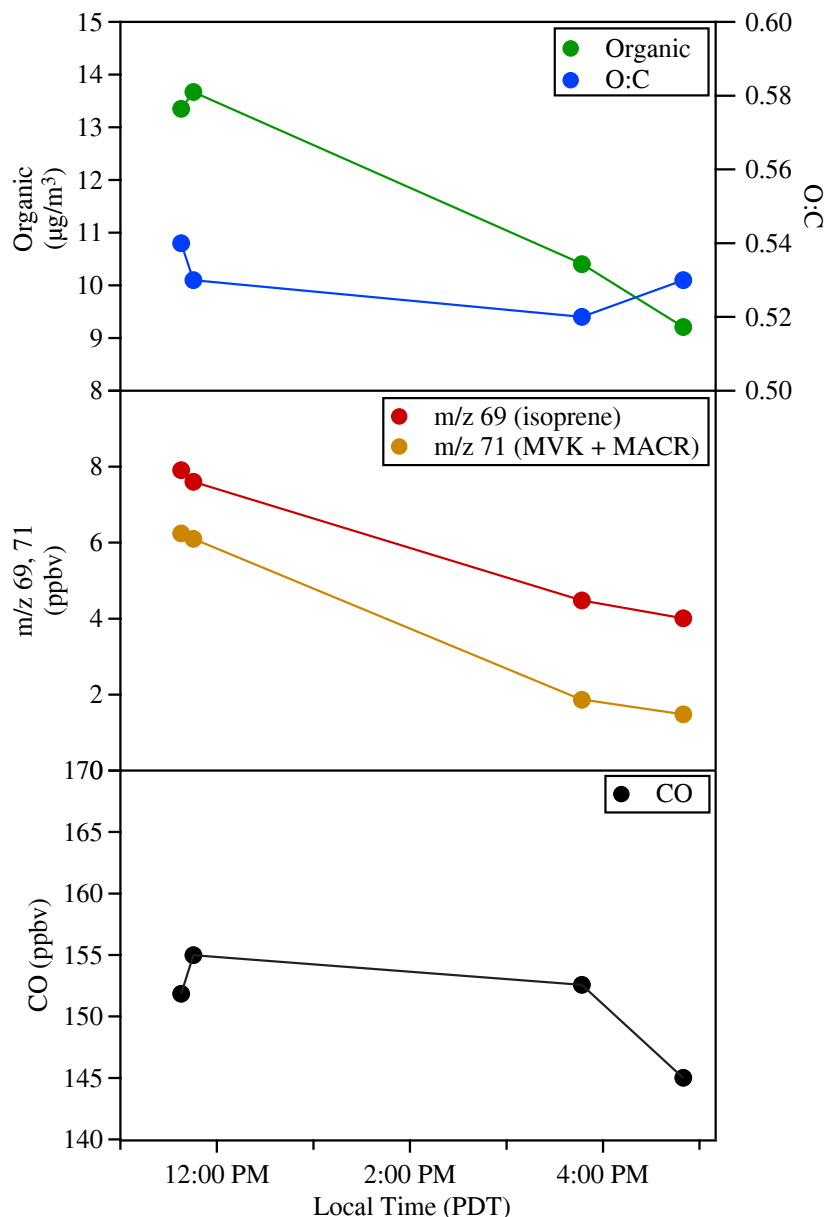

Fig. 7. Evolution of the average concentration of OA, CO, and biogenic tracers on the 28 June flights for a region of the flight domain influenced predominantly by fresh biogenic emissions (labeled d and $g$ in Figs. 3 and 4). Each point is the average of approximately $170 \mathrm{~s}$ of data representing a pass of the G-1 through the region. Lines are shown to guide the eye.

morning and in the afternoon. $\mathrm{CO}$ and ozone levels were $150-155$ and $45-60 \mathrm{ppbv}$ in the morning and $145-155$ and $50-60 \mathrm{ppbv}$ in the afternoon, indicating that the Sacramento urban plume highlighted in the previous section did not impact this area. At the same time, both CO and ozone levels are elevated relative to the values found in this same region on earlier days, indicating that this regions is influenced by aged urban emissions. Taken together, observations show that this area of the CARES domain is rich in fresh biogenic emissions and influenced by regional aged urban emissions, but unaffected by fresh anthropogenic emissions, thus providing an interesting contrast to OA evolution in the mixed anthropogenic/biogenic emission case. Comparisons of OA evolution for different airmasses on the same day are particularly informative as they normalize the effect of several variables, such as solar intensity and temperature, on OA production and allow us to focus in on the effect of emissions. 


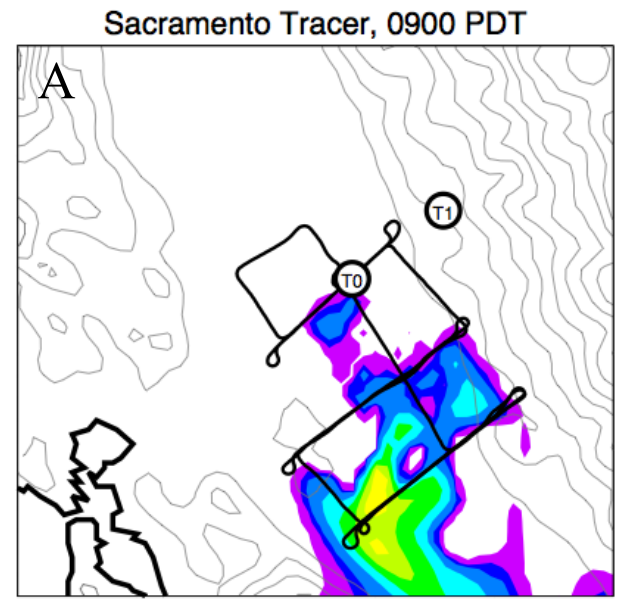

Sacramento Tracer, 1530 PDT

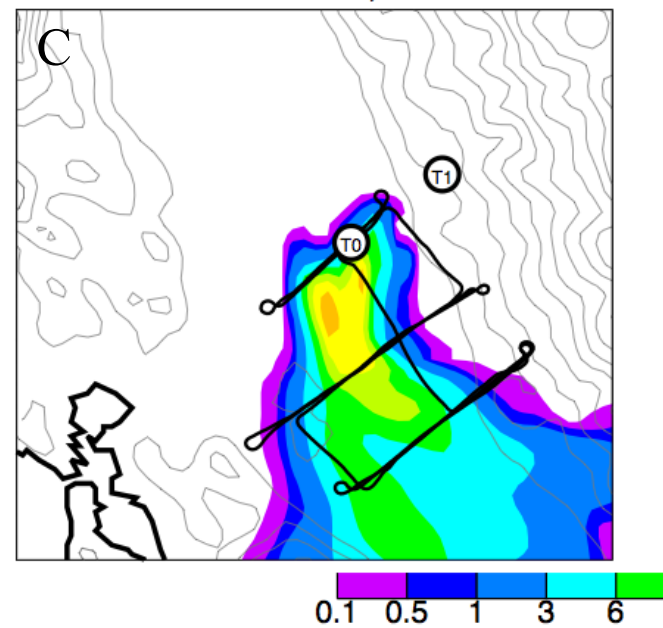

Bay Area Tracer, 0900 PDT

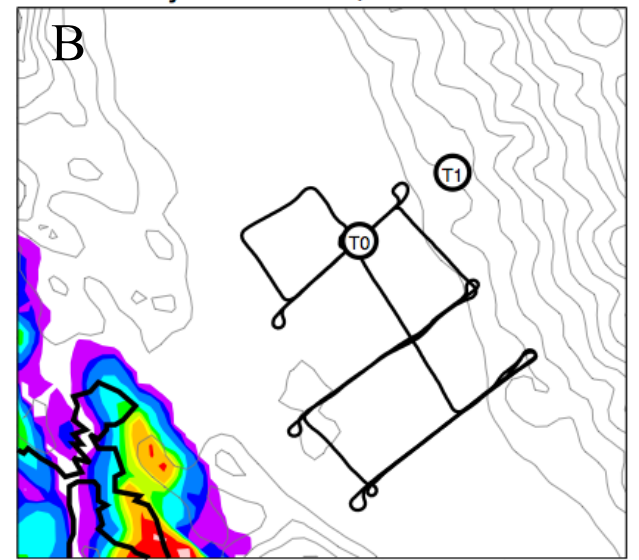

Bay Area Tracer, 1530 PDT

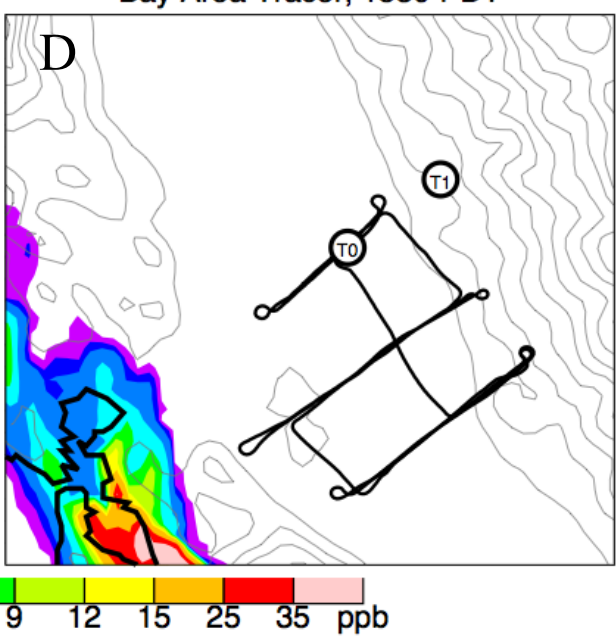

Fig. 8. WRF-Chem tracer forecasts of CO concentrations for central California on 12 June. (A) and (C) show the Sacramento urban area CO forecasts for 09:00 and 15:30 PDT respectively, which represent the approximate takeoff time of the morning and afternoon G-1 flights. (B) and (D) show CO forecasts for Bay Area emissions. The color scale indicates the level of CO above the background. The solid black line is the G-1 flight path and the markers show the locations of the ground sites.

Figure 7 shows the average values of $\mathrm{CO}, \mathrm{OA}, \mathrm{OA} \mathrm{O}: \mathrm{C}$, and biogenic tracers for the biogenically influenced portion of the 28 June G-1 flights (labeled d and $g$ in Figs. 3 and 4). The observed OA levels over this portion of the flight path are significant in both the morning and again in the afternoon, with OA concentrations of $12-15 \mu \mathrm{g} \mathrm{m}^{-3}$. As with the mixed emission case, the observed OA concentrations in the afternoon $\left(\sim 12 \mu \mathrm{g} \mathrm{m}^{-3}\right)$ are slightly lower than those observed in the morning. However, CO concentrations observed in the afternoon over this region are nearly identical to those observed in the morning, indicating that OA levels are not significantly affected by fresh anthropogenic emissions or by dilution from background air. Thus, in this region of the flight path, our data indicate that there was little or no net OA production between our morning and afternoon flight. The mass spectrum (Fig. 6) and O:C ratio of the $\mathrm{OA}$ in this biogenically influenced region of the flight path are identical to that observed in the mixed biogenic/anthropogenic plume, suggesting that the chemical composition of the aerosol in both cases is similar. We observed very high concentrations of both isoprene (up to $13.3 \mathrm{ppbv}$ ) and its oxidation products (up to $8 \mathrm{ppbv}$ ) in the region of the flight domain. Concentrations of both isoprene and its oxidation products decrease from the morning to the afternoon flight. Three possible explanations exist for this observation. First, photochemistry could oxidize both tracers, causing concentrations to decrease. We note that ozone concentrations in the area are significant (50-60 ppbv) and it is therefore reasonable to assume that significant concentrations of $\mathrm{OH}$ radical are also present to oxidize these biogenic emissions. A second possibility is that biogenic concentrations were simply diluted by either the growth of the boundary layer or by transport. The morning observations were made between 11:30 and 12:00, times when the boundary layer well developed; thus is unlikely that the rising boundary caused the significant decrease in concentrations. Transport is another possibility; however, winds 


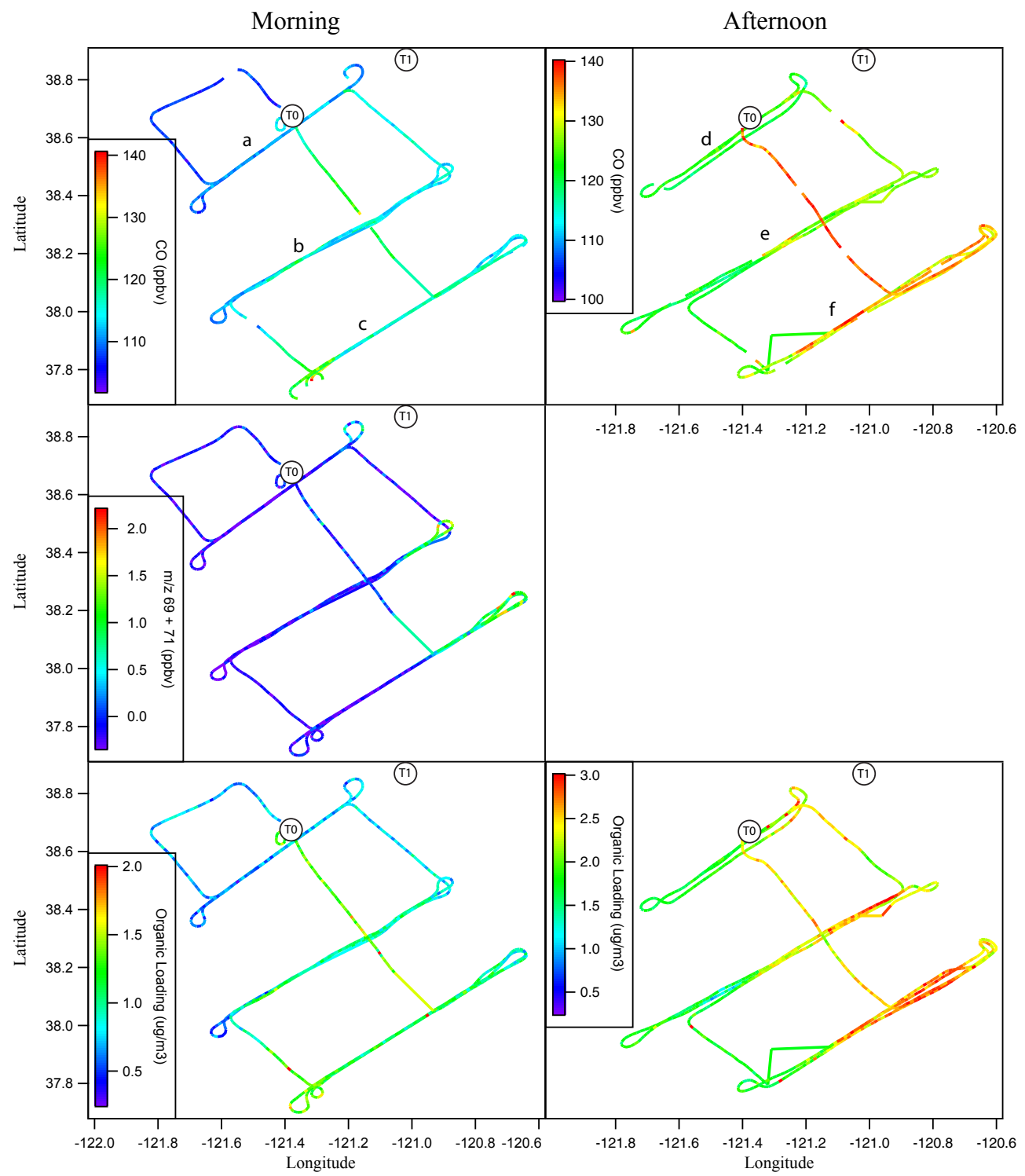

Fig. 9. 12 June morning and afternoon flight tracks colored by CO, the sum of $m / z 69$ (isoprene) and 71 (MVK + MACR), and OA concentrations. Note the low concentrations of biogenic tracers across the flight domain. PTR-MS data were not available in the afternoon flight. Letters are used to identify important portions of the flight track and correspond to the letters in shown in Fig. 10.

are relatively light on 28 June and isoprene emissions track temperature and would have thus continued through the day. In addition, we observe an increase in OA concentrations in the mixed plume, which had lower levels of isoprene. Thus, over this region of the foothills, we observe intense emissions of isoprene which is processed by photochemical reactions without a correlated increase in OA concentration. The aforementioned observations are in sharp contrast to the behavior described in Sect. 3.1 when the fresh emissions from Sacramento mixed with fresh biogenic emissions.

\subsection{Anthropogenic dominant plume evolution}

We next examine the evolution of OA mass in a plume dominated by urban emissions. As mentioned in section 3.3, the plume observed on the morning of 28 June had significant concentrations of isoprene and its oxidation products already present despite its close location to the city. We cannot identify a section of the 28 June flight that was affected only by anthropogenic emission and therefore must instead examine flight data from other days. For this purpose, flights made on days with winds out of the northwest provide a convenient case study to the evolution of a plume in the absence of biogenic emissions. Figure 8 shows WRF-Chem tracer forecasts 


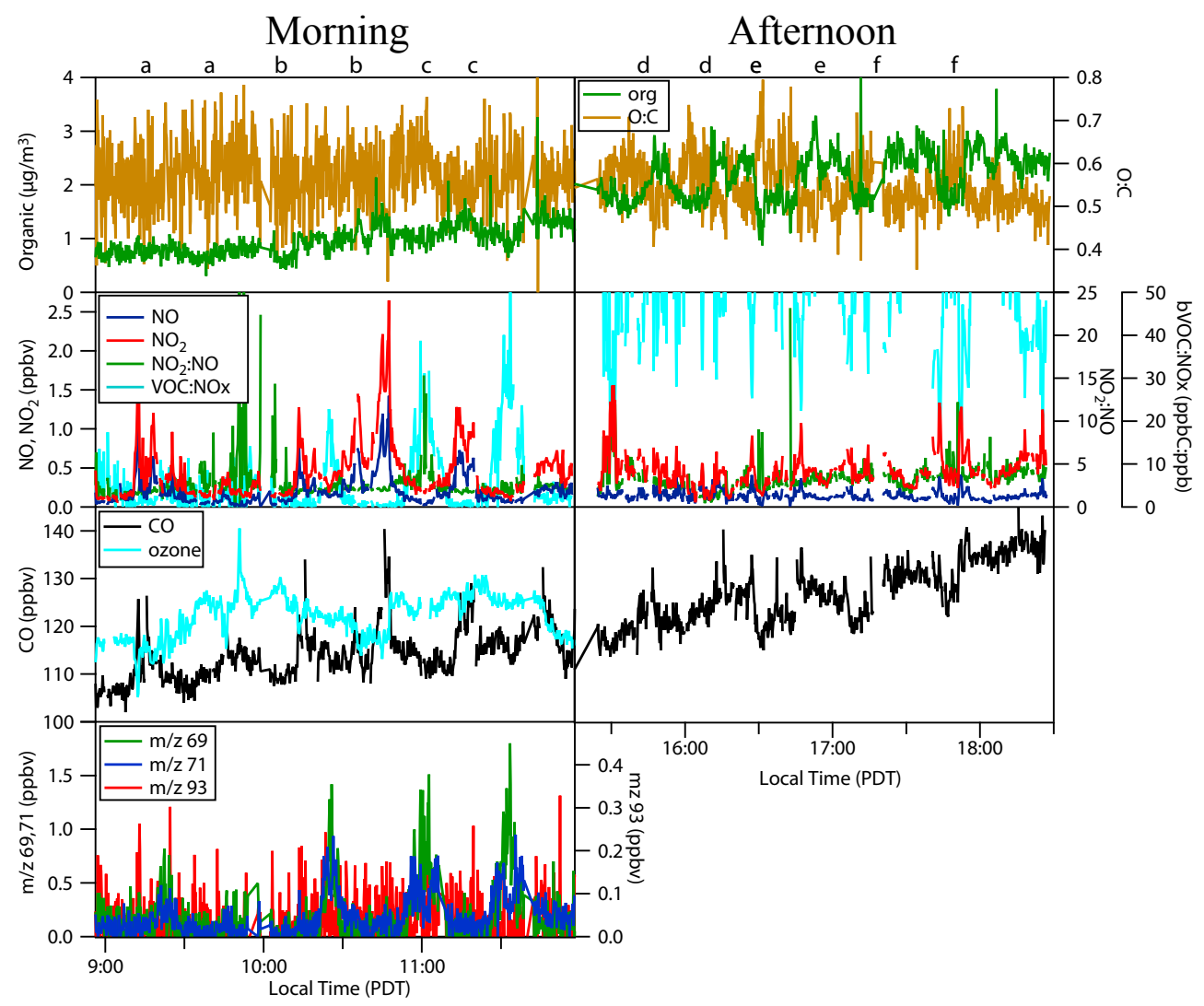

Fig. 10. Organic particle mass, organic particle O:C, $\mathrm{CO}$, ozone, $\mathrm{NO}, \mathrm{NO}_{2}, \mathrm{NO}_{2}: \mathrm{NO}, \mathrm{bVOC}: \mathrm{NO}_{\mathrm{x}}, m / z \quad 69$ (isoprene), $m / z \quad 71$ (MVK + MACR), and $\mathrm{m} / z 93$ (toluene) concentrations for the morning and afternoon 12 June flights. Note there is a break in the time axis. PTR-MS and ozone measurements were not available during the afternoon flights. Letters at the top of the graph correspond to the flight legs labeled in Fig. 9.

of both the Sacramento (a, c) and Bay Area (b, d) CO emissions for the morning and afternoon of 12 January. As seen in Fig. 8, the WRF-Chem model predicts that Sacramento emissions are transported almost due south into the central valley. The predictions show the plume is not transported to a significant extent into the foothills. Furthermore, the strong synoptic NW winds which developed on 10 June persisted until 13 June, making it unlikely that biogenic emissions from the foothills would be transported into the Sacramento area by nighttime downslope flow (Fast et al, 2012). Therefore, the Sacramento urban plume on this day should be largely free of biogenic influence, with the possible exception of the eastern-most portions of the flight legs. Tracer forecasts of Bay Area tracers show that these emissions are also transported to the south, but are not carried into the region sampled by the G-1. Therefore, the Sacramento plume should also be relatively free of emissions from the Bay Area, which may have different age and chemical composition than the Sacramento plume.

Figure 9 shows the spatial variation of G-1 observations of $\mathrm{OA}, \mathrm{CO}$, and biogenic tracers for both the morning and afternoon flight of 12 June (PTR-MS data are not available for the afternoon flight). Figure 10 shows similar measurements plotted temporally and include OA O:C and ozone measurements. The measurements largely confirm the WRF-Chem tracer predictions; the highest concentrations of $\mathrm{CO}$ are indeed south of the city. Measurements also confirm that OA evolved largely independent of biogenic influence with significant levels of biogenic emissions observed only when the eastern edges of the flight paths penetrating into the foothills. It is also clear that concentrations of all species are much lower on 12 June than on 28 June; OA levels on 12 June peak at $3 \mu \mathrm{g} \mathrm{m}^{-3}$ compared to $>25 \mu \mathrm{g} \mathrm{m}^{-3}$ on 28 June, CO levels peak at $140 \mathrm{ppbv}$ on 12 June and $>300 \mathrm{ppbv}$ on 28 June, and biogenic tracers peak at 3 ppbv on 12 June and $>14$ ppbv on 28 June. The higher wind speeds on 12 June, which reached as high as $15 \mathrm{~m} \mathrm{~s}^{-1}$ at the G-1 altitude, relative to those on 28 June $\left(\sim 2 \mathrm{~m} \mathrm{~s}^{-1}\right)$ contribute to more rapid dispersion of pollutants, lowering their concentrations (Fast et al., 2012; Zaveri et al., 2012). OA levels were observed to increase between the morning and the afternoon flights, though the increase was much smaller than that observed on 28 June. The average value of the OA O:C during the morning flight was 0.55 and no correlations were observed between O:C and OA loading, 
similar to the $\mathrm{O}: \mathrm{C}$ ratios observed for both the mixed plume and biogenically dominated cased discussed earlier. The average $\mathrm{O}: \mathrm{C}$ in the afternoon is approximately the same as in the morning, again similar to observations in the other cases examined earlier.

Interestingly, the OA mass spectrum on this day is indistinguishable from the OA spectrum for the mixed plume case and biogenically dominated case. In fact, all the representative mass spectra presented for each OA sample are indistinguishable from one another. Previous observations have shown that the properties of OA from multiple sources converge with atmospheric aging (Jimenez et al., 2009; $\mathrm{Ng}$ et al., 2010). However, we have demonstrated that fresh OA is produced rapidly in the mixed plume on 28 June. Thus, we conclude that the majority of the OA originates from similar sources, regardless of whether the air parcel is influenced primarily by biogenic emissions, anthropogenic emissions, or both. However, we show in the following section that the production rate of the $\mathrm{OA}$ is enhanced when biogenic and anthropogenic emissions mix in an air parcel.

\subsection{OA:CO and Statistical Analysis}

The slope of a plot of OA against CO provides a commonly used metric for the OA production rate (i.e., $\Delta \mathrm{OA} / \Delta \mathrm{CO}$ ). Because $\mathrm{CO}$ is a conserved tracer on the timescales of our measurements, plotting these two quantities against each other will normalize for dilution of an airmass by clean air. By examining the slope of the plot, $\Delta \mathrm{OA} / \Delta \mathrm{CO}$, the problem of correcting for background concentrations of both $\mathrm{CO}$ and OA, which are both difficult to determine, can be avoided. For this same reason, we have chosen not to attempt to subtract a background from the data and instead focus only on the slope, which will be unaffected by background as we are not forcing the data through the origin. This method is particularly useful for studying the evolution of an urban plume as $\mathrm{CO}$ emissions are much higher in the city than in surrounding areas, effectively making the city a large point source of CO. Recent observations and modeling studies have found significant $\mathrm{CO}$ production from photooxidation of biogenic emissions (Slowik et al., 2010; Miller et al., 2008). We assert that urban emissions are the dominant $\mathrm{CO}$ source during CARES for the following reasons. Flights were conducted within approximately 100 miles of Sacramento and $\mathrm{CO}$ was co-located with other urban emissions, such as $\mathrm{NO}_{\mathrm{x}}$. $\mathrm{CO}$ is always higher near the city and lower downwind while the biogenic emissions follow the opposite spatial trend, arguing for an urban $\mathrm{CO}$ source. $\mathrm{CO}$ yields from monoterpenes are larger than from isoprene while biogenic emissions in the CARES flight domain were dominated by isoprene (Slowik et al., 2010). Finally, a recent modeling study estimated that oxidation of biogenic VOCs contributes only $5 \mathrm{ppbv}$ of $\mathrm{CO}$ during summertime over the Sierra Nevada foothills (Worton et al., 2011).
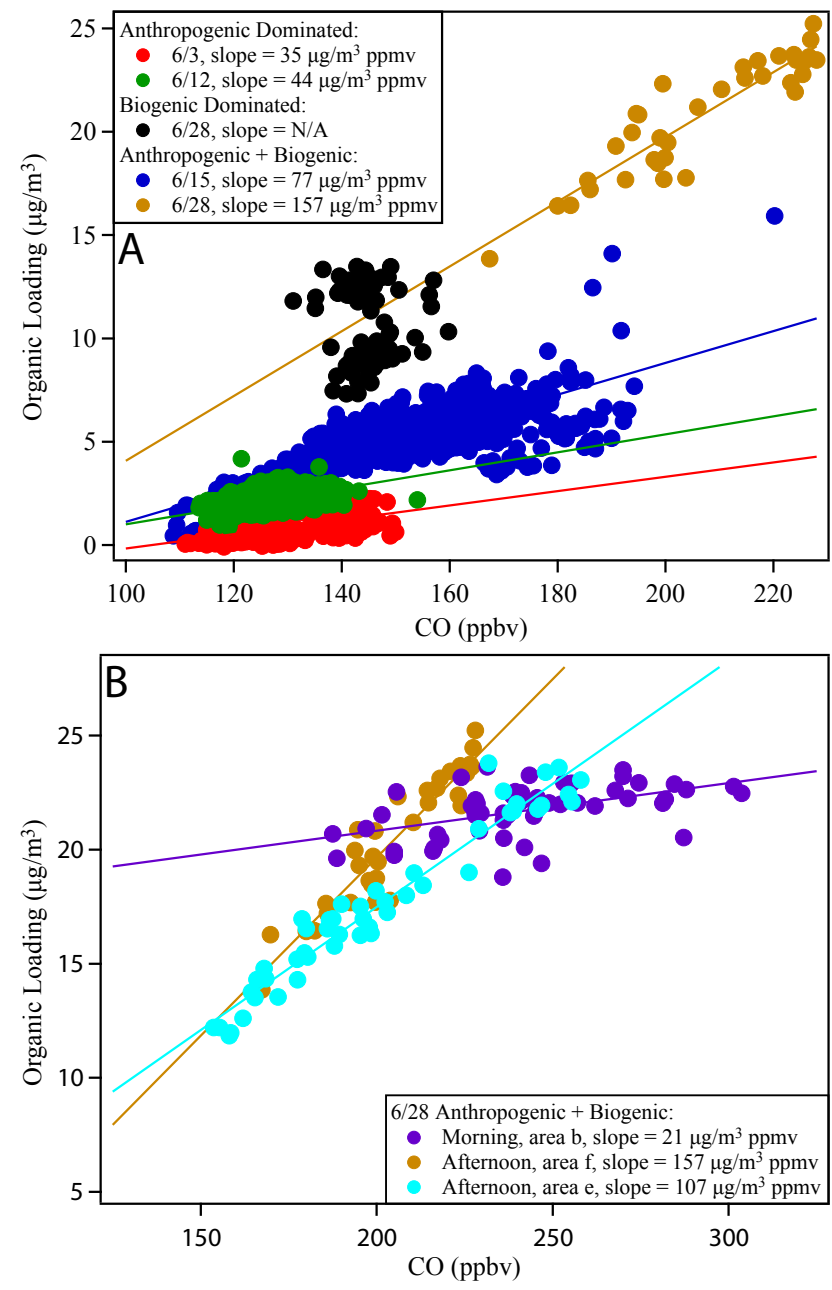

Fig. 11. Organic loading plotted against the $\mathrm{CO}$ concentration for CARES data according to the predominant emission sources influencing the airmass. The slope of these plots $(\triangle \mathrm{OA} / \triangle \mathrm{CO})$ gives a measure of the SOA production efficiency. All data in (A) are from the afternoon G-1 flights. A linear fit through the biogenic dominated 28 June data yielded a small, negative slope and is not shown for clarity. (B) Illustrates the evolution of $\Delta \mathrm{OA} / \Delta \mathrm{CO}$ in the mixed anthropogenic/biogenic plume on 28 June for the morning data (labeled $b$ in Figs. 3 and 4), the afternoon at the leading edge of the plume (labeled f in Figs. 3 and 4) where biogenic concentrations averaged $3.75 \mathrm{ppbv}$ in the afternoon, and at the trailing edge of the plume (labeled e in Figs. 3 and 4) where biogenic concentrations averaged $1.95 \mathrm{ppbv}$ in the afternoon.

In the absence of any OA production or evaporation, $\mathrm{CO}$ and SOA would dilute at the same rate. The flexibility of aircraft sampling allows us to follow the temporal evolution of a particular airmass and thus minimize the effects of different sources with distinct emission profiles complicating the analysis. Figure 11 shows AMS measured OA concentrations plotted against $\mathrm{CO}$ concentrations for individual flights or in some cases for particular regions of some flights. The $\triangle \mathrm{OA} / \triangle \mathrm{CO}$ values for each group of data are 
given in the legend. In panel a, we only plot data from afternoon flights, which typically were conducted between approximately 15:00 and 19:00 PDT so that SOA formation has had adequate time to occur. During the CARES study, SOA concentrations peaked around 14:00 at the T0 site and later at 16:00 at the T1 site (Setyan et al., 2012). Therefore, we expect the peak in SOA formation to occur around the time of the afternoon flight. Data are chosen and grouped according to whether the Sacramento urban plume was expected to evolve in the presence of biogenic emission (i.e., SW flow conditions) or in the absence of strong biogenic emissions (i.e., NW flow conditions). The slopes of these plots give a rough measure of the SOA formation rates with higher slopes indicating more efficient SOA formation. As seen in Fig. 11, there is a large range of $\triangle \mathrm{OA} / \triangle \mathrm{CO}$ values found during CARES, with a generally strong correlation observed between $\mathrm{OA}$ and $\mathrm{CO}$ for one particular flight. The largest $\Delta \mathrm{OA} / \Delta \mathrm{CO}$ value of $157 \mu \mathrm{g} \mathrm{m}^{-3} \mathrm{ppmv}$ was observed on 28 June, which is also the day we observe maximum OA loadings. As detailed in previous sections of the manuscript, the Sacramento plume on this day contained a mixture of fresh biogenic and anthropogenic emissions. We also included data from the flight on 15 June, a case we did not discuss in detail, but in which we found evidence for mixing of anthropogenic and biogenic emissions. The $\Delta \mathrm{OA} / \Delta \mathrm{CO}$ value on 15 June day is $77 \mu \mathrm{g} \mathrm{m}^{-3} \mathrm{ppmv}$, relatively close to those values found in Mexico City $\left(62 \mu \mathrm{g} \mathrm{m}^{-3} \mathrm{ppmv}\right)$ and during the NEAQS campaign ( $63 \mu \mathrm{g} \mathrm{m}^{-3}$ ppmv) (Kleinman et al., 2008; Weber et al., 2007). We note that the concentrations of biogenic tracers found in the morning near the city were much lower on 15 June, possibly resulting in less efficient OA productions relative to 28 June case. These G- $\Delta \mathrm{OA} / \Delta \mathrm{CO}$ values are consistent with those measured the T1 site when, where the average $\Delta \mathrm{OA} / \Delta \mathrm{CO}$ value was $93 \mu \mathrm{g} \mathrm{m}^{-3} \mathrm{ppmv}$ and as high as $196 \mu \mathrm{g} \mathrm{m}^{-3}$ ppmv when anthropogenic and biogenic emissions mixed (Setyan et al., 2012).

In contrast, the $\triangle \mathrm{OA} / \triangle \mathrm{CO}$ is much smaller for days on which the Sacramento plume was transported south and evolved in the absence of biogenic emissions. The $\Delta \mathrm{OA} / \Delta \mathrm{CO}$ values on 3 and 12 June are 35 and $44 \mu \mathrm{g} \mathrm{m}^{-3}$ ppmv, respectively much smaller than the value observed on the days where the anthropogenic and biogenic emissions mixed, but similar to value of $41 \mu \mathrm{g} \mathrm{m}^{-3} \mathrm{ppmv}$ found off the coast of New England (de Gouw et al., 2008) and to the average value of $35 \mu \mathrm{g} \mathrm{m}^{-3}$ ppmv measured under similar conditions at the T1 site (Setyan et al., 2012). Data from the portions of the 28 June flight path influenced predominantly by biogenic emissions is also shown. A fit through this data displays a near zero negative slope, as $\mathrm{CO}$ values remained near background and there is no measurable increase in OA concentrations. Thus, the differences in the $\Delta \mathrm{OA} / \triangle \mathrm{CO}$ values of the different airmasses indicate that $\mathrm{OA}$ production is 2-4 times more efficient when anthropogenic and biogenic emissions mix than when emissions evolve in isolation.
Evolution of $\triangle \mathrm{OA} / \triangle \mathrm{CO}$ within the mixed anthropogenic/biogenic plume on 28 June is further evaluated in Fig. 11, panel b. In the morning, fresh anthropogenic emissions, including $\mathrm{CO}$, are injected into the plume, while photochemistry and OA production have not yet peaked. As a result, $\Delta \mathrm{OA} / \Delta \mathrm{CO}$ in the plume is $21 \mu \mathrm{g} \mathrm{m}^{-3} \mathrm{ppmv}$, much smaller than observed in the afternoon on this and other days. Also shown in Panel B is a comparison of $\Delta \mathrm{OA} / \Delta \mathrm{CO}$ in the leading (area $\mathrm{f}$ in Figs. 3 and 4 ) and trailing (area e in Figs. 3 and 4) edges of the mixed plume for the afternoon of 28 June. The plume in both regions has the same nominal photochemical age and similar concentration of CO. However, the leading edge of the plume has larger concentrations of isoprene ( $3.75 \mathrm{ppbv}$ on average) than the trailing edge ( $1.95 \mathrm{ppbv}$ isoprene) because it is located deeper into the foothills where isoprene emissions are larger. As a result, $\Delta \mathrm{OA} / \Delta \mathrm{CO}$ is 1.5 times larger in the leading edge of the plume $\left(157 \mu \mathrm{g} \mathrm{m}^{-3} \mathrm{ppmv}\right)$ than in the trailing edge of the plume (107 $\mu \mathrm{g} \mathrm{m}^{-3}$ ppmv), again suggesting that fresh isoprene emissions are key in generating OA within the mixed plume.

$\triangle \mathrm{OA} / \triangle \mathrm{CO}$ has been shown to increase with the photochemical age of an airmass (Kleinman et al., 2008; de Gouw et al., 2008). We are unfortunately unable to identify a pair of species that can be used as a photochemical clock; $\mathrm{NO}_{\mathrm{y}}$ measurements were not available on the G-1 while benzene and toluene concentrations quickly fall below the instrument limit of detection outside of downtown Sacramento. Observations of isoprene and MVK + MACR in 28 June mixed plume near Sacramento despite their short photochemical lifetime indicates that the plume has been influenced by fresh biogenic emissions (Figs. 4, 5). Fresh urban emissions are also clearly observed. At the same time, the WRF-Chem simulations also show that recirculation events transported some emissions from the previous day back to the city, making estimations of the photochemical age of the plume even more difficult. In Sect. 3.6, we discuss the HR-AMS observations in the context of the OA production mechanism; results suggest that photochemical aging is not as important in the Sacramento area in determining OA production rates as has been demonstrated in other regions.

To further support the hypothesis that mixtures of biogenic and anthropogenic emissions are more efficient at producing OA mass, we performed a statistical analysis of the data. We computed the upper quartiles for all the $\mathrm{CO}$, isoprene and MVK + MACR measurements taken on the G-1 during CARES. CO is taken as a tracer for all anthropogenic emissions and the sum of isoprene, MVK and MACR are taken as a tracer for biogenic emissions. We note that our choice of biogenic tracers for this type of analysis is somewhat flawed because the lifetime of both tracers to attack by $\mathrm{OH}$ is relatively short $(\sim 1 \mathrm{~h}$ for isoprene and $\sim 4 \mathrm{~h}$ for MVK/MACR assuming $[\mathrm{OH}]=3 \times 10^{6}$ molecules $\mathrm{cm}^{-1}$ ); therefore, we feel it is possible that the high-anthropogenic/low-biogenic case is biased 


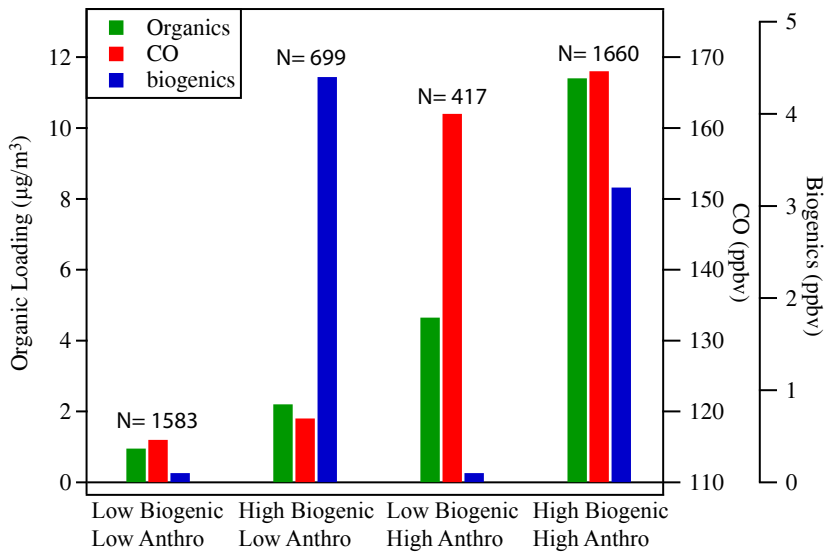

Fig. 12. Median OA loading for data that has been binned according to anthropogenic $(\mathrm{CO})$ and biogenic (isoprene + MVK + MACR) tracer concentrations. Tracer concentrations are categorized as "low" if they fall in the lower quartile of all data and "high" if they fall in the upper quartile. Median CO and biogenic tracer concentrations for each bin are also shown. The number of points in each bin is indicated above the bars.

high due to the presence of more aged biogenic emissions that escape PTR-MS quantification. Unfortunately, it is difficult to identify a long-lived tracer for biogenic emissions from the available measurements. OA concentrations are binned into four categories based on the co-located gas-phase tracer measurements: low anthropogenic and biogenic emissions, which represent data with both biogenic and anthropogenic tracer concentrations falling in the lowest quartile; high biogenic emissions and low anthropogenic emissions, which represents data with biogenic tracer concentration in the upper quartile and anthropogenic tracer concentrations in the lower quartile; high anthropogenic emissions and low biogenic emissions, representing data with anthropogenic tracer concentrations in the upper quartile and biogenic concentrations in the lower quartile; and high anthropogenic and biogenic emissions, which represents data with both anthropogenic and biogenic tracers in the upper quartile. The median of OA levels in each of these four categories is shown in Fig. 12. Conditions with low biogenic and anthropogenic emissions produced the lowest median OA concentrations, $1.0 \mu \mathrm{g} \mathrm{m}^{-3}$, which are close to the values reported for remote continental air (Zhang et al., 2007). Median OA levels were higher in the case of high biogenic and low anthropogenic emissions, $2.2 \mu \mathrm{g} \mathrm{m}^{-3}$, and higher still in the case of high anthropogenic but low biogenic emissions, $4.7 \mu \mathrm{g} \mathrm{m}^{-3}$. However, there is a marked increase in median OA levels when both anthropogenic and biogenic tracer concentrations are high, $11.4 \mu \mathrm{g} \mathrm{m}^{-3}$. The OA concentration in the high anthropogenic and biogenic case is in fact significantly greater than the sum of the median OA levels from the high anthropogenic and high biogenic cases, again suggesting that OA levels are enhanced when biogenic and anthropogenic emissions mix.
The trends we see in this analysis are consistent with the trends we see in OA:CO ratios with biogenic dominated airmasses displaying the least efficient OA production, anthropogenic dominated airmasses displaying more efficient OA production and the mixed biogenic anthropogenic airmasses displaying the most efficient OA production.

\subsection{Evaluation of SOA formation mechanisms}

Finally, we use the data presented earlier to evaluate the SOA formation mechanism(s) and biogenic/anthropogenic interactions that have been proposed to lead to enhanced SOA formation in the literature. We emphasize that our conclusions pertain to this data set; some mechanism may be more or less important for SOA formation in other locations and under other conditions.

Some literature mechanisms can be readily eliminated due to the timing of the mission and the G-1 flights. First, all flights were conducted during the daytime (09:00-18:00) well away from dawn and dusk; therefore oxidation of VOCs by $\mathrm{NO}_{3}$, will be negligible. We also note that our observations were made under clear-sky conditions, ruling out generation of OA mass from in-cloud aqueous-phase processing. There were no major forest fires or biomass burns on the days we detail in this work and the biomass burning organic aerosol fraction at T0 and T1 sites was small (Zaveri et al., 2012; Setyan et al., 2012; Vaden et al., 2011). While we have not performed PMF analysis of the G-1 AMS data, the low signal at $\mathrm{m} / \mathrm{z} 60$ and 73 in the AMS (Fig. 6) and low acetonitrile concentrations measured by the PTR-MS, all tracers of biomass burning, support the conclusion that biomass burning particles did not drive OA formation.

The HR-AMS-determined OA elemental ratios further constrain the mechanism. These data show that, while the OA concentrations increased significantly as the plume evolved on 28 June, the O:C elemental ratio did not. In fact, the $\mathrm{O}: \mathrm{C}$ ratios observed inside the mixed urban/biogenic plume were similar to those observed outside the plume in areas with strong biogenic influence. These O:C data suggest that, mechanistically, the increase in OA concentrations observed are best explained by continued production of SOA from fresh VOC precursors, at least over the observation timescales. The particle-phase O:C ratio increases when gasphase aging of semi- or intermediate volatility species produces additional OA mass (DeCarlo et al., 2010; Donahue et al., 2012) while we observe no such increases in O:C. Therefore, our observations are in contrast OA production from this mechanism (DeCarlo et al., 2010; Donahue et al., 2012; Robinson et al., 2007). Our observations are consistent with chamber observations of both the absolute values and time-evolution of the $\mathrm{O}: \mathrm{C}$ ratio of fresh SOA produced from the photochemical oxidation of isoprene in the presence of $\mathrm{NO}_{\mathrm{x}}$ (Chhabra et al., 2010); though as noted in Sect. 3.2, the literature isoprene yield appears too low to explain the increase in OA mass. 
The HR-AMS data can also be used to rule out large contributions of organosulfates and organonitrates to the total OA mass loading. As mentioned in Sect. 3.1, the data suggest a small excess of anion mass over the mass required for complete neutralization of the measured cation signal. Some of this excess signal may come from the systematic error associated with instrument calibration, but organonitrates and organosulfates could also possibly contribute (Farmer et al., 2010). We unambiguously separate and identify a small number of ions that retain a C-N or C-O-N bond in the AMS; however, their combined signal intensity is only $0.6 \%$ of the total organic signal. The ratio of the signal intensity at $\mathrm{m} / \mathrm{z}, 30$ (NO) to $\mathrm{m} / \mathrm{z} 46\left(\mathrm{NO}_{2}\right)$ may also indicate the presence of organonitrates (Farmer et al., 2010; Bruns et al., 2010; Liu et al., 2012). During CARES flights this ratio was variable, but within the range observed during instrument calibration with pure ammonium nitrate particles, which suggests that organonitrate concentrations are small. We are unable to observe any ions that retain a C-S bond, though this does not definitively rule out the presence of organosulfates (Farmer et al., 2010). Even assuming that the $\sim 20 \%$ excess of anion mass originates entirely from organosulfates and organonitrates; they still comprise a minor fraction (roughly $1 \%$ ) of the total organic mass. Setyan et al. (2012) discuss AMS measurements of organonitrates and organosulfates at the T1 site during CARES in detail and also conclude that they are likely present, but in minor quantities.

Acidification of particles has also been suggested to promote enhanced SOA formation through acid-catalyzed oligomerization reactions and formation of organic-sulfate esters (Gao et al., 2004; Offenberg et al., 2009; Jang et al., 2002). As mentioned in the previous section, we do not see significant evidence of organic sulfate formation. Unfortunately, we have no measurements that directly assess oligomer concentrations in the aerosol. The observed anion/cation balance, abundance of nitrate in the particles, and large ammonia concentrations emitted in the Sacramento Valley all suggest that the aerosol particles are largely neutralized. AMS measurements confirmed that the particles are nearly fully neutralized at the T1 ground site (Setyan et al., 2012). Organic acids potentially increase the particle acidity, though it is not clear how anthropogenic emissions would promote the enhancement of organic acid formation necessary for explaining our observations. Based on these indirect measurements of particle acidity, we conclude that acidification of particles is unlikely to be responsible for the enhanced OA formation observed during CARES.

When $\mathrm{NO}_{\mathrm{x}}$ concentrations are low, isoprene derived peroxyradicals react with $\mathrm{HO}_{2}$, eventually generating epoxydiols that, in the presence of sulfate seed aerosol, heterogeneously produce SOA in high yield (Surratt et al., 2010; Lin et al., 2012). This mechanism is promising in that it produces very high SOA yields from isoprene while our observations suggest that isoprene is the key biogenic VOC leading to OA formation in this area (Surratt et al., 2010). Signal intensity at $m / z$ 82, specifically the $\mathrm{C}_{5} \mathrm{H}_{6} \mathrm{O}^{+}$ion, has been identified as an AMS marker for SOA formation from isoprene epoxydiols (Lin et al., 2012; Robinson et al., 2011). Robinson et al. (2011) performed PMF analysis of AMS data collected in a tropical rainforest and identify a factor characterized by strong signal intensity at $\mathrm{m} / \mathrm{z} 82$ which they attribute to SOA formation from isoprene (Robinson et al., 2011). They report that the signal intensity at $\mathrm{m} / \mathrm{z} 82$ is $2 \%$ of the organic signal (i.e., 82:org) and that $82 \%$ of the signal at $\mathrm{m} / \mathrm{z} 82$ was from the $\mathrm{C}_{5} \mathrm{H}_{6} \mathrm{O}^{+}$ion (i.e., $\mathrm{C}_{5} \mathrm{H}_{6} \mathrm{O}^{+}: m / z$ 82) (Robinson et al., 2011). Lin et al. (2012) examined heterogeneous SOA formation from isoprene epoxydiols in the presence of acidic sulfate seed and report 82:org of $1-2 \%$ and $\mathrm{C}_{5} \mathrm{H}_{6} \mathrm{O}^{+}: \mathrm{m} / z, 82$ of $68-95 \%$ (Lin et al., 2012). We observe relatively small but significant signal intensity at $\mathrm{m} / \mathrm{z}, 82$ in nearly all mass spectra, regardless of the dominant emission sources (Fig. 6). In the mixed anthropogenic/biogenic plume described in Section 3.2, 82:org was $0.6 \%$ while $\mathrm{C}_{5} \mathrm{H}_{6} \mathrm{O}^{+}: \mathrm{m} / z, 82$ was $63 \%$ (Fig. 6). Data are very similar for the other mass spectra presented in Fig. 6. Therefore, in our data, the $\mathrm{C}_{6} \mathrm{H}_{10}^{+}$ion is a somewhat smaller portion of the signal at $\mathrm{m} / \mathrm{z} 82$ than observed by Lin et al. (2012) and Robinson et al. (2011) and the $m / z 82$ peak is a somewhat smaller portion of the total organic signal. Additionally, efficient SOA formation from isoprene epoxydiols requires acidic sulfate seed, while the aerosol was largely neutralized during CARES (Surratt et al., 2010). In light of this evidence, we conclude that isoprene epoxydiol formation may contribute to OA formation during CARES, though it is unlikely to explain our observations of increased OA productions in mixed biogenic/anthropogenic emissions.

SOA yield from isoprene has been show to reach a maximum for VOC: $\mathrm{NO}_{\mathrm{x}}$ ratios of between 1-5 (ppbv C: ppbv $\mathrm{NO}_{\mathrm{x}}$ ) (Kroll et al., 2005; Kroll et al., 2006; Dommen et al., 2006; Chan et al., 2010). As shown in Fig. 4, the ratio of biogenic VOCs to $\mathrm{NO}_{\mathrm{x}}$ (bVOC:NO $\mathrm{N}_{\mathrm{x}}$ ) in the 28 June plume ranges between 2 and 6 in both the morning and the afternoon. Much higher ratios, often in excess of 20, are found outside the plume in the biogenically influenced portions of the 28 June flight track, lending support to a $\mathrm{NO}_{\mathrm{x}}$-mediated enhancement of $\mathrm{OA}$ formation from the photooxidation of isoprene. Though not discussed in detail in this manuscript, we also observe larger $\Delta \mathrm{OA} / \triangle \mathrm{CO}$ values and OA concentrations on the afternoon of 15 June (Fig. 11). The bVOC: $\mathrm{NO}_{\mathrm{x}}$ ratios in the 15 June plume are approximately 5 , again falling into the range where isoprene SOA yield reaches a maximum. The concentrations of both biogenic VOCs and OA are low on the morning 12 June flight and PTR-MS data are unfortunately unavailable in the afternoon (Fig. 10), so we are unable to determine the bVOC: $\mathrm{NO}_{\mathrm{x}}$ ratio in the afternoon. We emphasize that we observe portions of the flight track on 12 June with relatively high $\mathrm{NO}_{\mathrm{x}}$ concentrations yet still see very low $\mathrm{OA}$ concentrations and $\Delta \mathrm{OA} / \Delta \mathrm{CO}$ values, again suggesting that anthropogenic emissions alone do not produce significant OA in the Sacramento regions. Thus, our 
data suggests that the bVOC: $\mathrm{NO}_{\mathrm{x}}$ ratio plays an important role in regulating $\mathrm{OA}$ formation from isoprene in this region and may partially drive our observations of enhanced OA formation in mixed anthropogenic/biogenic plumes. However, the precise mechanism for this enhancement remains unclear. As discussed in the preceding paragraph, our observations suggest that conditions are not favorable for efficient production of SOA from isoprene under low- $\mathrm{NO}_{\mathrm{x}}$ conditions. Under high- $\mathrm{NO}_{\mathrm{x}}$ conditions, $\mathrm{SOA}$ production is attributed to the formation and subsequent oxidation of MPAN (Chan et al., 2010; Surratt et al., 2010). In this case, high ratios of $\mathrm{NO}_{2}$ :NO should favor production of MPAN and therefore OA production. In the afternoon of 28 June, the $\mathrm{NO}_{2}: \mathrm{NO}$ ratio was $1.5-2 \times$ higher in the mixed plume than outside of it (Fig. 4). However, significant OA production was also observed during the morning flight where the $\mathrm{NO}_{2}$ : $\mathrm{NO}$ ratio did not change significantly as the G-1 passed in and out of the mixed plume. Finally, SOA production via the MPAN pathway generates condensed-phase organic nitrates (Chan et al., 2010; Surratt et al., 2010). While we can't rule out small contributions of organic nitrates to the OA mass, the data suggests they are not a major fraction of the OA mass. Thus, the CARES data suggest $\mathrm{NO}_{\mathrm{x}}$ plays some role in enhancing SOA formation in the mixed anthropogenic/biogenic plume, though the mechanism remains unclear. A full model simulation is required for determining whether the laboratory measured $\mathrm{NO}_{\mathrm{x}}$-dependent isoprene yields can fully account for the measured SOA loadings. Further research is also needed to determine whether the relationship between the bVOC: $\mathrm{NO}_{\mathrm{x}}$ ratio and OA production rates is robust.

\section{Conclusions and atmospheric implications}

In summary, we found that the aerosol particles in the Sacramento area were $85 \%$ organic by mass and appear to be completely or nearly completely neutralized. Isoprene dominated the biogenic VOC emissions, with monoterpene concentrations below the instrument limit of detection. Differences in wind direction and transport patterns combined with the flexibility of aircraft sampling allowed us to investigate the evolution of this organic mass when emission sources were primarily anthropogenic, biogenic, or a mixture of both. We use median OA concentrations and $\Delta \mathrm{OA} / \Delta \mathrm{CO}$ values as the metrics to evaluate OA production from these emissions sources. Under NW flow conditions, the Sacramento plume was transported into the Sacramento Valley and the OA evolved largely in the absence of biogenic emissions. In this case, median OA concentrations are $4.7 \mu \mathrm{g} \mathrm{m}^{-3}$ and $\Delta \mathrm{OA} / \Delta \mathrm{CO}$ ratios of $35-44 \mu \mathrm{g} \mathrm{m}^{-3} \mathrm{ppmv}$, similar to the value of $41 \mu \mathrm{g} \mathrm{m}^{-3}$ ppmv found off the coast of New England (de Gouw et al., 2008). For regions of strong biogenic emissions unaffected by fresh anthropogenic emissions, we find median $\mathrm{OA}$ values of $2.2 \mu \mathrm{g} \mathrm{m}^{-3}$, and near zero $\Delta \mathrm{OA} / \Delta \mathrm{CO}$ ratios. During the 28 June flight, we iden- tified an area of intense biogenic emissions that had been affected by aged anthropogenic emissions, yet we measure little to no OA production despite favorable photochemical conditions and observations of intense OA production nearby. Under SW flow conditions, the Sacramento plume was transported to the Sierra Nevada foothills where foliage produced strong isoprene emissions. When biogenic and anthropogenic emissions mix, OA levels are enhanced with median OA concentrations of $11.4 \mu \mathrm{g} \mathrm{m}^{-3}$ and $\Delta \mathrm{OA} / \Delta \mathrm{CO}$ ratios of $77-157 \mu \mathrm{g} \mathrm{m}^{-3}$ ppmv. The highest OA concentrations and $\triangle \mathrm{OA} / \triangle \mathrm{CO}$ ratios were observed in the mixed plume on the 28 June flight in sharp contrast to our observations in the biogenically influenced portion of the same flight track. These results show that anthropogenic and biogenic emissions interact to enhance OA production from biogenic species. After considering multiple possible anthropogenic/biogenic interaction mechanisms, we conclude that $\mathrm{NO}_{\mathrm{x}}$ concentrations play some role in enhancing SOA formation from isoprene, though the chemical mechanism for the enhancement remains unclear. This conclusion is supported by laboratory measurement showing that SOA products and yields from isoprene are a strongly dependent on the gas-phase oxidation pathways, which are complexly dependent on the relative concentrations of $\mathrm{NO}, \mathrm{NO}_{2}, \mathrm{HO}_{2}$, and $\mathrm{RO}_{2}$ (Kroll et al., 2005; Kroll et al., 2006; Dommen et al., 2006; Chan et al., 2010; Surratt et al., 2010).

Further research is needed to determine whether our observations represent a robust feature of isoprene SOA chemistry or are unique to summertime OA production in the Sacramento region. Anthropogenic emissions from urban areas mix with biogenic emissions, including isoprene, in large portions of the world. A full accounting of the regional and global atmospheric implications of the effect of anthropogenic/biogenic interactions requires detailed photochemical modeling studies, which, to our knowledge, currently do not include the complex $\mathrm{NO}_{\mathrm{x}}$-dependent isoprene SOA mechanisms and yields reported in the literature. The current best estimates suggest that $50-70 \%$ of the total OA budget may be composed of SOA produced from biogenic VOC's, but controlled by anthropogenic emissions (Carlton et al., 2010; Spracklen et al., 2011). Our data suggest that SOA production is enhanced by a factor of 2-4 when biogenic and anthropogenic emissions mix during summertime in the Sacramento region. Regardless of the uncertainty in the magnitude of this effect, it is clear from this work and the work of others that the interactions of biogenic and anthropogenic emissions do significantly influence OA formation and must be included in models if they are to reproduce observed OA concentrations for the correct mechanistic reasons. 
Acknowledgements. The authors thank the G-1 flight and ground crews for supporting the CARES mission. Funding for data collection onboard the G-1 aircraft and at the ground sites was provided by the Atmospheric Radiation Measurement (ARM) Climate Research Facility sponsored by the U.S. Department of Energy (DOE), Office of Biological and Environmental Research (OBER). Partial support was also provided by the Environmental Molecular Sciences Laboratory (EMSL), a national scientific user facility sponsored by the DOE's OBER at Pacific Northwest National Laboratory (PNNL). Data analysis and research was supported by the US DOE's Atmospheric System Research Program under Contract DE-AC06-76RLO 1830 at PNNL. PNNL is operated for the US DOE by Battelle Memorial Institute.

Edited by: D. J. Cziczo

\section{References}

Aiken, A. C., DeCarlo, P. F., and Jimenez, J. L.: Elemental analysis of organic species with electron ionization high-resolution mass spectrometry, Anal. Chem., 79, 8350-8358, 2007.

Allan, J. D., Coe, H., Bower, K. N., Alfarra, M. R., Delia, A. E., Jimenez, J. L., Middlebrook, A. M., Drewnick, F., Onasch, T. B., Canagaratna, M. R., Jayne, J. T., and Worsnop, D. R.: Technical Note: Extraction of chemically resolved mass spectra from Aerodyne aerosol mass spectrometer data, J. Aerosol Sci., 35, 909-922, 2004.

Amann, A., Schwarz, K., Wimmer, G., and Witkovsky, V.: Model Based Determination of Detection Limits for Proton Transfer Reaction Mass Spectrometer, Meas. Sci. Rev., 10, 180-188, doi:10.2478/v10048-010-0031-5, 2010.

Asa-Awuku, A., Miracolo, M. A., Kroll, J. H., Robinson, A. L., and Donahue, N. M.: Mixing and phase partitioning of primary and secondary organic aerosols, Geophys. Res. Lett., 36, L15827, doi:10.1029/2009g1039301, 2009.

Bahreini, R., Dunlea, E. J., Matthew, B. M., Simons, C., Docherty, K. S., DeCarlo, P. F., Jimenez, J. L., Brock, C. A., and Middlebrook, A. M.: Design and operation of a pressure-controlled inlet for airborne sampling with an aerodynamic aerosol lens, Aerosol Sci. Technol., 42, 465-471, doi:10.1080/02786820802178514, 2008.

Bruns, E. A., Perraud, V., Zelenyuk, A., Ezell, M. J., Johnson, S. N., Yu, Y., Imre, D., Finlayson-Pitts, B. J., and Alexander, M. L.: Comparison of FTIR and Particle Mass Spectrometry for the Measurement of Particulate Organic Nitrates, Environ. Sci. Technol., 44, 1056-1061, doi:10.1021/es9029864, 2010.

Canagaratna, M. R., Jayne, J. T., Jimenez, J. L., Allan, J. D., Alfarra, M. R., Zhang, Q., Onasch, T. B., Drewnick, F., Coe, H., Middlebrook, A., Delia, A., Williams, L. R., Trimborn, A. M., Northway, M. J., DeCarlo, P. F., Kolb, C. E., Davidovits, P., and Worsnop, D. R.: Chemical and microphysical characterization of ambient aerosol with the Aerodyne aerosol mass spectrometer, Mass. Spectrom. Rev., 26, 185-222, 2007.

Carlton, A. G., Turpin, B. J., Lim, H.-J., Altieri, K. E., and Seitzinger, S. P.: Link between isoprene and secondary organic aerosol (SOA): Pyruvic acid oxidation yields low volatility oranic acids in clouds, Geophys. Res. Lett., 33, L06822, doi:10.1029/2005GL025374, 2006.
Carlton, A. G., Pinder, R. W., Bhave, P. V., and Pouliot, G. A.: To What Extent Can Biogenic SOA be Controlled?, Environ. Sci. Technol., 44, 3376-3380, doi:10.1021/es903506b, 2010.

Chan, A. W. H., Chan, M. N., Surratt, J. D., Chhabra, P. S., Loza, C. L., Crounse, J. D., Yee, L. D., Flagan, R. C., Wennberg, P. O., and Seinfeld, J. H.: Role of aldehyde chemistry and $\mathrm{NO}_{\mathrm{x}}$ concentrations in secondary organic aerosol formation, Atmos. Chem. Phys., 10, 7169-7188, doi:10.5194/acp-10-7169-2010, 2010.

Chhabra, P. S., Flagan, R. C., and Seinfeld, J. H.: Elemental analysis of chamber organic aerosol using an aerodyne high-resolution aerosol mass spectrometer, Atmos. Chem. Phys., 10, 4111-4131, doi:10.5194/acp-10-4111-2010, 2010.

de Gouw, J. A., Brock, C. A., Atlas, E. L., Bates, T. S., Fehsenfeld, F. C., Goldan, P. D., Holloway, J. S., Kuster, W. C., Lerner, B. M., Matthew, B. M., Middlebrook, A. M., Onasch, T. B., Peltier, R. E., Quinn, P. K., Senff, C. J., Stohl, A., Sullivan, A. P., Trainer, M., Warneke, C., Weber, R. J., and Williams, E. J.: Sources of particulate matter in the northeastern United States in summer: 1. Direct emissions and secondary formation of organic matter in urban plumes, J. Geophys. Res.-Atmos., 113, D08301, doi:10.1029/2007jd009243, 2008.

DeCarlo, P. F., Kimmel, J. R., Trimborn, A., Jayne, J. T., Aiken, A. C., Gonin, M., Fuhrer, K., Horvath, T., Docherty, K. S., Worsnop, D. R., and Jimenez, J. L.: A Field-Deployable High-Resolution Time-of-Flight Aerosol Mass Spectrometer, Anal. Chem., 78, 8281-8289, 2006.

DeCarlo, P. F., Ulbrich, I. M., Crounse, J., de Foy, B., Dunlea, E. J., Aiken, A. C., Knapp, D., Weinheimer, A. J., Campos, T., Wennberg, P. O., and Jimenez, J. L.: Investigation of the sources and processing of organic aerosol over the Central Mexican Plateau from aircraft measurements during MILAGRO, Atmos. Chem. Phys., 10, 5257-5280, doi:10.5194/acp-10-52572010, 2010.

deGouw, J. A., Middlebrook, A. M., Warneke, C., Goldan, P. D., Kuster, W. C., Roberts, J. M., Fehsenfeld, F. C., Worsnop, D. R., Canagaratna, M. R., Pszenny, A. A. P., Keene, W. C., Marchewka, M., Bertman, S. B., and Bates, T. S.: Budget of organic carbon in a polluted atmosphere: Results from the New England Air Quality Study in 2002, J. Geophys. Res., 110, D16305, doi:10.1029/2004JD005623, 2005.

Dommen, J., Metzger, A., Duplissy, J., Kalberer, M., Alfarra, M. R., Gascho, A., Weingartner, E., Prevot, A. S. H., Verheggen, B., and Baltensperger, U.: Laboratory observation of oligomers in the aerosol from isoprene/ $\mathrm{NO}_{\mathrm{x}}$ photooxidation, Geophys. Res. Lett., 33, L13805, doi:10.1029/2006g1026523, 2006.

Donahue, N. M., Henry, K. M., Mentel, T. F., Kiendler-Scharr, A., Spindler, C., Bohn, B., Brauers, T., Dorn, H. P., Fuchs, H., Tillmann, R., Wahner, A., Saathoff, H., Naumann, K. H., Mohler, O., Leisner, T., Muller, L., Reinnig, M. C., Hoffmann, T., Salo, K., Hallquist, M., Frosch, M., Bilde, M., Tritscher, T., Barmet, P., Praplan, A. P., DeCarlo, P. F., Dommen, J., Prevot, A. S. H., and Baltensperger, U.: Aging of biogenic secondary organic aerosol via gas-phase $\mathrm{OH}$ radical reactions, Proc. Natl. Acad. Sci. USA, 109, 13503-13508, doi:10.1073/pnas.1115186109, 2012.

Dzepina, K., Volkamer, R. M., Madronich, S., Tulet, P., Ulbrich, I. M., Zhang, Q., Cappa, C. D., Ziemann, P. J., and Jimenez, J. L.: Evaluation of recently-proposed secondary organic aerosol models for a case study in Mexico City, Atmos. Chem. Phys., 9, 5681-5709, doi:10.5194/acp-9-5681-2009, 2009. 
Ervens, B., Carlton, A. G., Turpin, B. J., Kreidenweis, S. M., and Feingold, G.: Secondary organic aerosol yields from cloudprocessing of isoprene oxidation products, Geophys. Res. Lett., 35, L02816, doi:10.1029/2007GL031828, 2008.

Farmer, D. K., Matsunaga, A., Docherty, K. S., Surratt, J. D., Seinfeld, J. H., Ziemann, P. J., and Jimenez, J. L.: Response of an aerosol mass spectrometer to organonitrates and organosulfates and implications for atmospheric chemistry, Proc. Natl. Acad. Sci. USA, 107, 6670-6675, doi:10.1073/pnas.0912340107, 2010.

Fast, J. D., Jr., W. I. G., Berg, L. K., Shaw, W. J., Pekour, M., Barnard, J., Ferrare, R. A., Hostetler, C. A., Erickson, M., Jobson, B. T., Flowers, B., Manvendra, D., Springston, S., Pierde, B., Dolislager, L., Pederson, J., and Zaveri, R. A.: Transport and Mixing Pattern over Central California during the Carbonaceous Aerosol and Radiative Effects Study (CARES), Atmos. Chem. Phys., 1759-1783, doi:10.5194/acp-12-1759-2012, 2012.

Gao, S., Ng, N. L., Keywood, M., Varutbangkul, V., Bahreini, R., Nenes, A., He, J. W., Yoo, K. Y., Beauchamp, J. L., Hodyss, R. P., Flagan, R. C., and Seinfeld, J. H.: Particle phase acidity and oligomer formation in secondary organic aerosol, Environ. Sci. Technol., 38, 6582-6589, 2004.

Goldstein, A. H., Koven, C. D., Heald, C. L., and Fung, I. Y.: Biogenic carbon and anthropogenic pollutants combine to form a cooling haze over the southeastern United States, Proc. Natl. Acad. Sci. USA, 106, 8835-8840, doi:10.1073/pnas.0904128106, 2009.

Guenther, A., Karl, T., Harley, P., Wiedinmyer, C., Palmer, P. I., and Geron, C.: Estimates of global terrestrial isoprene emissions using MEGAN (Model of Emissions of Gases and Aerosols from Nature), Atmos. Chem. Phys., 6, 3181-3210, doi:10.5194/acp-63181-2006, 2006.

Heald, C. L., Jacob, D. J., Park, R. J., Russell, L. M., Huebert, B. J., Seinfeld, J. H., Liao, H., and Weber, R. J.: A large organic aerosol source in the free troposphere missing from current models, Geophys. Res. Lett., 32, L18809, doi:10.1029/2005GL023831, 2005.

Hodzic, A., Jimenez, J. L., Madronich, S., Canagaratna, M. R., DeCarlo, P. F., Kleinman, L., and Fast, J.: Modeling organic aerosols in a megacity: potential contribution of semi-volatile and intermediate volatility primary organic compounds to secondary organic aerosol formation, Atmos. Chem. Phys., 10, 5491-5514, doi:10.5194/acp-10-5491-2010, 2010.

Hoyle, C. R., Boy, M., Donahue, N. M., Fry, J. L., Glasius, M., Guenther, A., Hallar, A. G., Hartz, K. H., Petters, M. D., Petaja, T., Rosenoern, T., and Sullivan, A. P.: A review of the anthropogenic influence on biogenic secondary organic aerosol, Atmos. Chem. Phys., 11, 321-343, doi:10.5194/acp-11-321-2011, 2011.

Jang, M., Czoschke, N. M., Lee, S., and Kamens, R. M.: Heterogeneous Atmospheric Aerosol Production by Acid-Catalyzed Particle-Phase Reactions, Science, 298, 814-817, 2002.

Jayne, J. T., Leard, D. C., Zhang, X., Davidovits, P., Smith, K. A., Kolb, C. E., and Worsnop, D. R.: Development of an Aerosol Mass Spectrometer for Size and Composition Analysis of Submicron Particles, Aerosol Sci. Technol., 33, 49-70, 2000.

Jimenez, J. L., Canagaratna, M. R., Donahue, N. M., Prevot, A. S. H., Zhang, Q., Kroll, J. H., DeCarlo, P. F., Allan, J. D., Coe, H., Ng, N. L., Aiken, A. C., Docherty, K. S., Ulbrich, I. M., Grieshop, A. P., Robinson, A. L., Duplissy, J., Smith, J. D., Wilson, K. R., Lanz, V. A., Hueglin, C., Sun, Y. L., Tian, J., Laak- sonen, A., Raatikainen, T., Rautiainen, J., Vaattovaara, P., Ehn, M., Kulmala, M., Tomlinson, J. M., Collins, D. R., Cubison, M. J., Dunlea, E. J., Huffman, J. A., Onasch, T. B., Alfarra, M. R., Williams, P. I., Bower, K., Kondo, Y., Schneider, J., Drewnick, F., Borrmann, S., Weimer, S., Demerjian, K., Salcedo, D., Cottrell, L., Griffin, R., Takami, A., Miyoshi, T., Hatakeyama, S., Shimono, A., Sun, J. Y., Zhang, Y. M., Dzepina, K., Kimmel, J. R., Sueper, D., Jayne, J. T., Herndon, S. C., Trimborn, A. M., Williams, L. R., Wood, E. C., Middlebrook, A. M., Kolb, C. E., Baltensperger, U., and Worsnop, D. R.: Evolution of Organic Aerosols in the Atmosphere, Science, 326, 1525-1529, doi:10.1126/science.1180353, 2009.

Jobson, B. T., Alexander, M. L., Maupin, G. D., and Muntean, G. G.: On-line analysis of organic compounds in diesel exhaust using a proton transfer reaction mass spectrometer (PTR-MS), Int. J. Mass Spectrom., 245, 78-89, doi:10.1016/j.ijms.2005.05.009, 2005.

Kanakidou, M., Seinfeld, J. H., Pandis, S. N., Barnes, I., Dentener, F. J., Facchini, M. C., VanDingenen, R., Ervens, B., Nenes, A., Nielsen, C. J., Swietlicki, E., Putaud, J. P., Balkanski, Y., Fuzzi, S., Horth, J., Moortgat, G. K., Winterhalter, R., Myhre, C. E. L., Tsigaridis, K., Vignati, E., Stephanou, E. G., and Wilson, J.: Organic aerosol and global climate modelling: a review, Atmos. Chem. Phys., 5, 1053-1123, doi:10.5194/acp-5-1053-2005, 2005.

Karl, T. G., Christian, T. J., Yokelson, R. J., Artaxo, P., Hao, W. M., and Guenther, A.: The Tropical Forest and Fire Emissions Experiment: method evaluation of volatile organic compound emissions measured by PTR-MS, FTIR, and GC from tropical biomass burning, Atmos. Chem. Phys., 7, 5883-5897, doi:10.5194/acp-7-5883-2007, 2007.

Kleinman, L. I., Springston, S. R., Daum, P. H., Lee, Y. N., Nunnermacker, L. J., Senum, G. I., Wang, J., Weinstein-Lloyd, J., Alexander, M. L., Hubbe, J., Ortega, J., Canagaratna, M. R., and Jayne, J.: The time evolution of aerosol composition over the Mexico City plateau, Atmos. Chem. Phys., 8, 1559-1575, doi:10.5194/acp-8-1559-2008, 2008.

Kroll, J. H., Ng, N. L., Murphy, S. M., Flagan, R. C., and Seinfeld, J. H.: Secondary organic aerosol formation from isoprene photooxidation under high- $\mathrm{NO}_{\mathrm{x}}$ conditions, Geophys. Res. Lett., 32, L18808, doi:10.1029/2005GL023637, 2005.

Kroll, J. H., Ng, N. L., Murphy, S. M., Flagan, R. C., and Seinfeld, J. H.: Secondary organic aerosol formation from isoprene photooxidation, Environ. Sci. Technol., 40, 1869-1877, 2006.

Lin, Y. H., Zhang, Z. F., Docherty, K. S., Zhang, H. F., Budisulistiorini, S. H., Rubitschun, C. L., Shaw, S. L., Knipping, E. M., Edgerton, E. S., Kleindienst, T. E., Gold, A., and Surratt, J. D.: Isoprene Epoxydiols as Precursors to Secondary Organic Aerosol Formation: Acid-Catalyzed Reactive Uptake Studies with Authentic Compounds, Environ. Sci. Technol., 46, 250258, doi:10.1021/es202554c, 2012.

Lindinger, W., Hansel, A., and Jordan, A.: On-line monitoring of volatile organic compounds at pptv levels by means of protontransfer-reaction mass spectrometry (PTR-MS) - Medical applications, food control and environmental research, Int. J. Mass Spectrom., 173, 191-241, 1998.

Liu, S., Shilling, J. E., Song, C., Hiranuma, N., Zaveri, R. A., and Russell, L. M.: Hydrolysis of organonitrate functional groups in aerosol particles, Aerosol Sci. Technol., 46, 1359-1369, 
doi:10.1080/02786826.2012.716175, 2012.

Miller, S. M., Matross, D. M., Andrews, A. E., Millet, D. B., Longo, M., Gottlieb, E. W., Hirsch, A. I., Gerbig, C., Lin, J. C., Daube, B. C., Hudman, R. C., Dias, P. L. S., Chow, V. Y., and Wofsy, S. C.: Sources of carbon monoxide and formaldehyde in North America determined from high-resolution atmospheric data, Atmos. Chem. Phys., 8, 7673-7696, doi:10.5194/acp-8-7673-2008, 2008.

Ng, N. L., Canagaratna, M. R., Zhang, Q., Jimenez, J. L., Tian, J., Ulbrich, I. M., Kroll, J. H., Docherty, K. S., Chhabra, P. S., Bahreini, R., Murphy, S. M., Seinfeld, J. H., Hildebrandt, L., Donahue, N. M., DeCarlo, P. F., Lanz, V. A., Prevot, A. S. H., Dinar, E., Rudich, Y., and Worsnop, D. R.: Organic aerosol components observed in Northern Hemispheric datasets from Aerosol Mass Spectrometry, Atmos. Chem. Phys., 10, 46254641, doi:10.5194/acp-10-4625-2010, 2010.

Odum, J. R., Hoffmann, T., Bowman, F., Collins, D., Flagan, R., and Seinfeld, J. H.: Gas/particle partitioning and secondary organic aerosol yields, Environ. Sci. Technol., 30, 2580-2585, 1996.

Offenberg, J. H., Lewandowski, M., Edney, E. O., Kleindienst, T. E., and Jaoui, M.: Influence of Aerosol Acidity on the Formation of Secondary Organic Aerosol from Biogenic Precursor Hydrocarbons, Environ. Sci. Technol., 43, 7742-7747, doi:10.1021/es901538e, 2009.

Pankow, J. F.: An Absorption-Model of Gas-Particle Partitioning of Organic-Compounds in the Atmosphere, Atmos. Environ., 28, 185-188, 1994.

Perraud, V., Bruns, E. A., Ezell, M. J., Johnson, S. N., Yu, Y., Alexander, M. L., Zelenyuk, A., Imre, D., Chang, W. L., Dabdub, D., Pankow, J. F., and Finlayson-Pitts, B. J.: Nonequilibrium atmospheric secondary organic aerosol formation and growth, Proc. Natl. Acad. Sci. USA, 109, 2836-2841, doi:10.1073/pnas.1119909109, 2012.

Robinson, A. L., Donahue, N. M., Shrivastava, M. K., Weitkamp, E. A., Sage, A. M., Grieshop, A. P., Lane, T. E., Pierce, J. R., and Pandis, S. N.: Rethinking Organic Aerosols: Semivolatile Emissions and Photochemical Aging, Science, 315, 1259-1262, 2007.

Robinson, N. H., Hamilton, J. F., Allan, J. D., Langford, B., Oram, D. E., Chen, Q., Docherty, K., Farmer, D. K., Jimenez, J. L., Ward, M. W., Hewitt, C. N., Barley, M. H., Jenkin, M. E., Rickard, A. R., Martin, S. T., McFiggans, G., and Coe, H.: Evidence for a significant proportion of Secondary Organic Aerosol from isoprene above a maritime tropical forest, Atmos. Chem. Phys., 11, 1039-1050, doi:10.5194/acp-11-1039-2011, 2011.

Schichtel, B. A., Malm, W. C., Bench, G., Fallon, S., McDade, C. E., Chow, J. C., and Watson, J. G.: Fossil and contemporary fine particulate carbon fractions at 12 rural and urban sites in the United States, J. Geophys. Res., 113, D02311, doi:10.1029/2007JD008605, 2008.

Setyan, A., Zhang, Q., Merkel, M., Knighton, W. B., Sun, Y., Song, C., Shilling, J. E., Onasch, T. B., Herndon, S. C., Worsnop, D. R., Fast, J. D., Zaveri, R. A., Berg, L. K., Wiedensohler, A., Flowers, B. A., Dubey, M. K., and Subramanian, R.: Characterization of submicron particles influenced by mixed biogenic and anthropogenic emissions using high-resolution aerosol mass spectrometry: results from CARES, Atmos. Chem. Phys., 12, 8131-8156, doi:10.5194/acp-12-8131-2012, 2012.

Shrivastava, M., Fast, J., Easter, R., Gustafson Jr, W. I., Zaveri, R. A., Jimenez, J. L., Saide, P., and Hodzic, A.: Modeling organic aerosols in a megacity: comparison of simple and complex representations of the volatility basis set approach, Atmos. Chem. Phys., 11, 6639-6662, doi:10.5194/acp-11-6639-2011, 2011.

Slowik, J. G., Stroud, C., Bottenheim, J. W., Brickell, P. C., Chang, R. Y. W., Liggio, J., Makar, P. A., Martin, R. V., Moran, M. D., Shantz, N. C., Sjostedt, S. J., van Donkelaar, A., Vlasenko, A., Wiebe, H. A., Xia, A. G., Zhang, J., Leaitch, W. R., and Abbatt, J. P. D.: Characterization of a large biogenic secondary organic aerosol event from eastern Canadian forests, Atmos. Chem. Phys., 10, 2825-2845, doi:10.5194/acp-10-2825-2010, 2010.

Solomon, S., Qin, D., Manning, M., Chen, Z., Marquis, M., Averyt, K. B., Tignor, M., and Miller, H. L.: Climate Change 2007: The Physical Science Basis. Contribution of Working Group I to the Fourth Assessment Report of the Intergovernmental Panel on Climate Change, Cambridge University Press, New York, USA, 2007.

Song, C., Zaveri, R. A., Alexander, M. L., Thorton, J. A., Madronich, S., Ortega, J. V., Zelenyuk, A., Yu, X.-Y., Laskin, A., and Maughan, D. A.: Effect of hydrophobic primary organic aerosols on secondary organic aerosol formation from ozonolysis of $\alpha$-pinene, Geophys. Res. Lett., 37, L20803, doi:10.1029/2007GL030720, 2007.

Spracklen, D. V., Jimenez, J. L., Carslaw, K. S., Worsnop, D. R., Evans, M. J., Mann, G. W., Zhang, Q., Canagaratna, M. R., Allan, J., Coe, H., McFiggans, G., Rap, A., and Forster, P.: Aerosol mass spectrometer constraint on the global secondary organic aerosol budget, Atmos. Chem. Phys., 11, 12109-12136, doi:10.5194/acp-11-12109-2011, 2011.

Sullivan, A. P. and Weber, R. J.: Chemical characterization of the ambient organic aerosol soluble in water: 2. Isolation of acid, neutral, and basic fractions by modified sizeexclusion chromatography, J. Geophys. Res.-Atmos., 111, D05315, doi:10.1029/2005jd006486, 2006.

Surratt, J. D., Gomez-Gonzalez, Y., Chan, A. W. H., Vermeylen, R., Shahgholi, M., Kleindienst, T. E., Edney, E. O., Offenberg, J. H., Lewandowski, M., Jaoui, M., Maenhaut, W., Claeys, M., Flagan, R. C., and Seinfeld, J. H.: Organosulfate formation in biogenic secondary organic aerosol, J. Phys. Chem. A, 112, 8345-8378, doi:10.1021/jp802310p, 2008.

Surratt, J. D., Chan, A. W. H., Eddingsaas, N. C., Chan, M. N., Loza, C. L., Kwan, A. J., Hersey, S. P., Flagan, R. C., Wennberg, P. O., and Seinfeld, J. H.: Reactive intermediates revealed in secondary organic aerosol formation from isoprene, Proc. Natl. Acad. Sci. USA, 107, 6640-6645, doi:10.1073/pnas.0911114107, 2010.

Vaden, T. D., Imre, D., Beranek, J., Shrivastava, M., and Zelenyuk, A.: Evaporation kinetics and phase of laboratory and ambient secondary organic aerosol, Proc. Natl. Acad. Sci. USA, 108, 2190-2195, doi:10.1073/pnas.1013391108, 2011.

Volkamer, R., Jimenez, J. L., SanMartini, F., Dzepina, K., Zhang, Q., Salcedo, D., Molina, L. T., Worsnop, D. R., and Molina, M. J.: Secondary organic aerosol formation from anthropogenic air pollution: Rapid and higher than expected, Geophys. Res. Lett., 33, L17811, doi:10.1029/2006GL026899, 2006.

Volz, A. and Kley, D.: A resonance-fluorescence instrument for the insitu measurement of atmospheric carbon-monoxide, J. Atmos. Chem., 2, 345-357, doi:10.1007/bf00130747, 1985.

Warneke, C., de Gouw, J. A., Kuster, W. C., Goldan, P. D., and Fall, R.: Validation of Atmospheric VOC Measurements 
by Proton-Transfer- Reaction Mass Spectrometry Using a GasChromatographic Preseparation Method, Environ. Sci. Technol., 37, 2494-2501, doi:10.1021/es026266i, 2003.

Warneke, C., Roberts, J. M., Veres, P., Gilman, J., Kuster, W. C., Burling, I., Yokelson, R., and de Gouw, J. A.: VOC identification and inter-comparison from laboratory biomass burning using PTR-MS and PIT-MS, Int. J. Mass Spectrom., 303, 6-14, doi:10.1016/j.ijms.2010.12.002, 2011.

Weber, R. J., Sullivan, A. P., Peltier, R. E., Russell, A., Yan, B., Zheng, M., de Gouw, J., Warneke, C., Brock, C., Holloway, J. S., Atlas, E. L., and Edgerton, E.: A study of secondary organic aerosol formation in the anthropogenic-influenced southeastern United States, J. Geophys. Res.-Atmos., 112, D13302, doi:10.1029/2007jd008408, 2007.

Worton, D. R., Goldstein, A. H., Farmer, D. K., Docherty, K. S., Jimenez, J. L., Gilman, J. B., Kuster, W. C., de Gouw, J., Williams, B. J., Kreisberg, N. M., Hering, S. V., Bench, G., McKay, M., Kristensen, K., Glasius, M., Surratt, J. D., and Seinfeld, J. H.: Origins and composition of fine atmospheric carbonaceous aerosol in the Sierra Nevada Mountains, California, Atmos. Chem. Phys., 11, 10219-10241, doi:10.5194/acp-1110219-2011, 2011

Zaveri, R. A., Shaw, W. J., Cziczo, D. J., Schmid, B., Ferrare, R. A., Alexander, M. L., Alexandrov, M., Arnott, W. P., Atkinson, D., Barnard, J. C., Berg, L. K., Beranek, J., Brichtel, F., Cahill, J. F., Cairns, B., Cappa, C. D., China, C., Comstock, J., Dubey, M. K., Easter, R. C., Erickson, M. H., Fast, J. D., Floerchinger, C., Flowers, B. A., Fortner, E., Gaffney, J. S., Gilles, M. K., Gorkowski, K., Gustafson, W. I., Gyawali, M., Hair, J., Harworth, J. W., Herndon, S., Hostetler, C., Hubbe, J. M., Jayne, J. T., Jeong, H., Jobson, B. T., Kassianov, E., Kleinman, L. I., Kolesar, K. R., Kluzek, C., Knighton, B., Kubatova, A., Kuang, C., Laskin, A., Laulainen, N., Mazzoleni, C., Mei, F., Moffet, R., Nelson, D., Obland, M., Onasch, T. B., Ottaviani, M., Pekour, M., Prather, K. A., Radney, J. G., Sedlacek, A., Senum, G., Setyan, A., Shilling, J. E., Shrivastava, M., Song, C., Springston, S. R., Subramanian, R., Suski, K., Tomlinson, J., Wallace, H. W., Wang, J., Worsnop, D. R., Zelenyuk, A., and Zhang, Q.: Overview of the 2010 Carbonaceous Aerosols and Radiative Effects Study (CARES), Atmos. Chem. Phys., 12, 7647-7687, doi:10.5194/acp-12-76472012, 2012.
Zhang, Q., Jimenez, J. L., Canagaratna, M. R., Allan, J. D., Coe, H., Ulbrich, I., Alfarra, M. R., Takami, A., Middlebrook, A. M., Sun, Y. L., Dzepina, K., Dunlea, E., Docherty, K., DeCarlo, P. F., Salcedo, D., Onasch, T., Jayne, J. T., Miyoshi, T., Shimono, A., Hatakeyama, S., Takegawa, N., Kondo, Y., Schneider, J., Drewnick, F., Borrmann, S., Weimer, S., Demerjian, K., Williams, P., Bower, K., Bahreini, R., Cottrell, L., Griffin, R. J., Rautianinen, J., Sun, J. Y., Zhang, Y. M., and Worsnop, D. R.: Ubiquity and dominance of oxygenated species in organic aerosols in anthropogenically-influenced Nothern Hemisphere midlatitudes, Geophys. Res. Lett., 34, L13801, doi:10.1029/2007GL029979, 2007.

Zhang, Q., Jimenez, J. L., Canagaratna, M. R., Ulbrich, I. M., Ng, N. L., Worsnop, D. R., and Sun, Y. L.: Understanding atmospheric organic aerosols via factor analysis of aerosol mass spectrometry: a review, Anal. Bioanal. Chem., 401, 3045-3067, doi:10.1007/s00216-011-5355-y, 2011. 